\title{
REVEALING MISCONDUCT BY PUBLIC OFFICIALS \\ THROUGH \\ GRAND JURY REPORTS
}

\author{
BARRY JEFFrey STERn $\dagger$
}

Table of Contents

INTRODUCTION $\ldots \ldots \ldots \ldots \ldots \ldots \ldots \ldots \ldots$

I. Common Law ORigins of the Reporting FunCTION ..............................

II. IDENTIFYING THE CoMPETING INTERESTS..........

A. Camden: The Public Interest and the Lack of Forum Objection ........................ $\quad 86$

1. The Public Interest ............... 90

2. The Lack of Forum Objection .......... 93

B. Hughes: Challenging the Public Interest and Highlighting the Competing Interests of the Public Official..............................

1. Abuse of the Reporting Function: New York's Response......................

2. Distinguishing Between Reports and Indictments ..........................

a. The Source of the Problem and the New Jersey Solution ..................

b. Problems with the New Jersey Solution. 105

C. The Watergate Report: Balancing the Competing Interests........................... 109

D. The Alaska Impeachment Report .......... 115

† Professor of Law, Western New England College School of Law. B.A. 1971, University of Michigan; J.D. 1975, University of Michigan. The author wishes to thank Professor Jerold $H$. Israel for reviewing and commenting on an earlier draft of this Article. The author is also grateful for the extensive and incisive editorial suggestions of Bart Heemskerk; the summer research grant provided by Dean Howard Kalodner; the support and encouragement of his colleagues Leora Harpaz, Sam Stonefield, and Keith Werhan; the tireless secretarial services of Stella Metzger; and the numerous suggestions, editorial assistance, and constant encouragement of Lea Kendall.

Before entering teaching, the author was an Assistant Attorney General in the Criminal Division of the Alaska Department of Law and in 1985 was a consultant to the criminal division on a variety of issues, including the Alaska Impeachment Report discussed in this Article. 
1. The Grand Jury Investigation and Report ..

2. The Watergate and Alaska Impeachment Reports Compared .................

III. Defining the SCOPE OF the RePoRting Function

A. Reports Revealing Violations of the Public Trust That Are Not Indictable . . . . . . . . . . . . . .

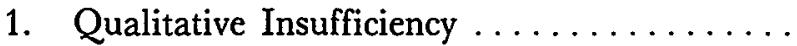

2. Quantitative Insufficiency .............

B. Reports Revealing Violations of the Public Trust When the Grand Jury Is Uncertain Whether or Not the Misconduct Is Indictable ............

C. The Use of a Report as an Alternative to a Prosecution............................

D. Adapting the Reporting Function to Provide a Viable Alternative to a Prosecution When a Violation of the Public Trust Is Indictable ..........

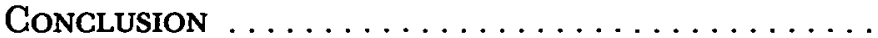

\section{INTRODUCTION}

Public officials owe a fiduciary duty to the public and therefore must comply with a more demanding standard of conduct than that required by the criminal law. ${ }^{1}$ Breaches of that fiduciary duty, some-

1 See United States v. Carter, 217 U.S. 286, 306 (1910) (public official, when acting as agent for the public, owes a fiduciary duty to the public); Shushan v. United States, 117 F.2d 110, 115 (5th Gir.) ("[n]o trustee has more sacred duties than a public official"), cert. denied, 313 U.S. 574 (1941); County of Cook v. Barrett, 36 Ill. App. 3d $623,628,344$ N.E.2d 540, 545 (1976) (when an elected "official acts as agent for the public body in business transactions, he owes to his principal duties of loyalty and good faith at least equal to those required of a private fiduciary in like circumstances"); State ex rel. Fletcher v. Naumann, 213 Iowa 418, 431, 239 N.W. 93, 99 (1931) ("public officers should so conduct their official duties as to be like Caesar's wife, 'above suspicion' of irregularities in the administration of their offices, even though such irregularities may not, under the law, constitute such willful misconduct . . . as to merit removal from office"); Burton Township of Genesee County v. Speck, 378 Mich. 213, 224, 144 N.W.2d 347, 350 (1966) (public officers owe "a duty of loyalty to the public no less than that of an agent to his principal"); State ex rel. Preissler v. Dostert, $163 \mathrm{~W}$. Va. $719,730,260$ S.E.2d 279, 286 (1979) ("public officer is in the position of a fiduciary and he is under an obligation to serve the public with highest fidelity and undivided loyalty'); see also infra note 4 (noting that a public officer may breach a fiduciary duty without commiting a criminal act).

Numerous jurisdictions have enacted ethics, conflict of interest, and financial disclosure laws comprehensively regulating the conduct of public officials. See, e.g., 2 U.S.C. $\$ \S 701-09$ (1982 \& Supp. III 1985) (financial disclosure by members of Congress and congressional employees); ARIz. REv. STAT. ANN. $\$ \S 38-311$ to -545 (1985) (conflict of interest, ethics, and financial disclosure legislation); Mass. GEN. Laws ANN. ch. 268A, §§ 4-24 (West 1980 \& West Supp. 1987) (conflict of interest laws and standards of conduct for state, county, and municipal employees). See generally Coun- 
times referred to as official misconduct or violations of the public trust, ${ }^{2}$ may not necessarily establish a crime, but can lead to a variety of other consequences that range from public criticism to removal from office. ${ }^{3}$

Cil. of State Governments, Ethics: State Conflict of Interest/Financial Disclosure Legislation 1972-75 (1975)(study of state laws attempting to curb ethical problems in state governments); Comment, Analysis of Financial Disclosure Laws of Public Officials, 18 ST. Lours U.L.J. 641, 641 (1974) (citing state conflict of interest statutes).

In this Article, the term "public official" refers to any government official or employee, whether elected or appointed.

${ }^{2}$ Public office is frequently referred to as a public trust. See, e.g., Uniformed Sanitation Men Ass'n v. Commissioner of Sanitation, 392 U.S. 280, 285 (1968) ("P]ublic employees subject themselves to dismissal if they refuse to account for the performance of their public trust, after proper proceedings, which do not involve an attempt to coerce them to relinquish their constitutional rights."); Benoit v. Gardner, 351 F.2d 846, 849 (1st Cir. 1965) ("[T]hose appointed to high public office hold a special public trust; they cannot properly complain if they are the objects of special scrutiny."); In re Report of Grand Jury, 152 Fla. 154, 160, 11 So. 2d 316, 319 (1943) ("Public office is the most important trust democratic government vests in the citizen."); County of Cook v. Barrett, 36 Ill. App. 3d 623, 627, 344 N.E.2d 540, 545 (1976) (Elected public officials hold positions "of the highest public trust."); THE FEDERALIST No. 65, at 396 (A. Hamilton) (Rossiter ed. 1961) (Impeachment power covers "those offenses which proceed from the misconduct of public men, or, in other words, from the abuse or violation of some public trust."). See generally Rogers \& Young, Public Office as a Public Trust: A Suggestion That Impeachment for High Crimes and Misdemeanors Implies a Fiduciary Standard, 63 GEo. L.J. 1025 (1975) (arguing that established fiduciary standard should be standard for impeachment).

${ }^{3}$ See, e.g., Golaine v. Cardinale, 142 N.J. Super. 385, 397, 361 A.2d 593, 599 (Law Div. 1976) ("removal for cause is a remedial proceeding, [and] that cause and the culpability upon which it is based need not necessarily involve either commission of a crime or an improper purpose"), aff d, 163 N.J. Super. 453, 395 A.2d 218 (App. Div. 1978), certif. denied, 79 N.J. 497, 401 A.2d 252 (1979); In re Brown, 512 S.W.2d 317,319 (Tex. 1974) (proceeding to remove judge is not a criminal proceeding and charges need not be established beyond reasonable doubt); State v. Geurts, 11 Utah 2d $345,348,359$ P.2d 12, 14 (1961) (public official may be removed from office for an act or omission which amounts to a crime, "which involves a substantial breach of the trust imposed upon the official by the nature of his office, and which conduct is of such a character as to offend against the commonly accepted standards of honesty and morality"), superseded by statute as stated in Madson v. Brown, 701 P.2d 1086, 1087 (Utah 1985); see also R. Berger, Impeachment: The Constitutional Problems 62 (1973) (concluding that federal constitutional standard for-impeachment, requiring proof of "high crimes and misdemeanors," is a term of art "without roots in the ordinary criminal law and which ... . had no relation to whether an indictment would lie in the particular circumstances"); Fenton, The Scope of the Impeachment Power, 65 Nw. U.L. REv. 719, 731 (1970) (constitutional framers intended "to include non-criminal misconduct within the catalog of impeachable offenses" (citation omitted)).

In some jurisdictions removal from office is a consequence of a criminal conviction for specified crimes and is a criminal sanction. See, e.g., N.C. GEN. STAT. § 14-228 to -230 (1981) (removal upon conviction for buying and selling offices, acting as officer before qualifying as such, or willful failure to discharge duties); TENN. CoDE ANN. $\S 39-5-401$ (1982) (removal from and disqualification from holding office upon misdemeanor conviction).

In this Article, the term "removal" is used generally to refer to any procedure which can result in the involuntary termination of a public official's term of office or employment, including termination at the discretion of an appointing authority or 
Grand juries that investigate allegations of official misconduct may often find it easier to conclude that a public official has committed a noncriminal rather than a criminal violation of the public trust.

For example, consider the situation in which a public official takes a discretionary action to benefit a campaign contributor without regard to the public's best interest. The criminality of that conduct depends on whether there is sufficient evidence to establish a violation of the criminal law beyond a reasonable doubt. However, even if the official did not commit a crime, the official did breach a fiduciary duty by placing a private interest above the public interest. ${ }^{4}$ If the grand jury does not charge the official with a crime, should it nevertheless have the authority to reveal the violation of the public trust?

There is a consensus among courts and commentators that, historically, common law grand juries performed a public reporting function by identifying official misconduct ${ }^{5}$ without initiating prosecution. ${ }^{\mathbf{b}}$

through a statutorily or constitutionally prescribed removal or impeachment proceeding. When a particular removal procedure is contemplated, the type of procedure is clearly identified.

4 See Anderson v. City of Parsons, 209 Kan. 337, 341, 496 P.2d 1333, 1337 (1972) ("[A] public officer owes an undivided duty to the public whom he serves and is not permitted to place himself in a position that will subject him to conflicting duties or cause him to act other than for the best interests of the public."); Preissler, $163 \mathrm{~W}$. Va. at 730,260 S.E.2d at 286 ("[P]ublic officer is in the position of a fiduciary and he is under an obligation to serve the public with highest fidelity and undivided loyalty."); see also Restatement (SECOND) OF AGENCY § 387 (1957) ("[A]n agent is subject to a duty to his principal to act solely for the benefit of the principal in all matters connected with his agency.").

- The scope of this Article is limited to examining reports that reveal misconduct by public officials. Therefore, the propriety of a report that concerns misconduct by private persons is not considered. It is uniformly held, however, that the reporting authority does not include the ability to criticize private persons. See Comment, The Propriety of a Breach of Grand Jury Secrecy When No Indictment Is Returned, 7 Hous. L. REv. 341, 352 (1970) (noting that a majority of courts hold that "criticism is the burden of holding public office," and that private citizens, not bearing that burden of the public trust, should not be subject to the public scorn of a critical report).

- See, e.g., In re Report and Recommendation of June 5, 1972 Grand Jury Concerning Transmission of Evidence to House of Representatives, 370 F. Supp. 1219, 1222-23 (D.D.C.) (grand jury permitted to transmit only a report to House Committee investigating impeachment of President), aff'd sub nom. Haldeman v. Sirica, 501 F.2d 714 (D.C. Cir. 1974); In re Presentment of Special Grand Jury Impaneled January, 1969, 315 F. Supp. 662, 675 (D. Md. 1970) ("[C]ommon law powers of a grand jury clearly include the power to make presentments, sometimes called reports, calling attention to certain actions of public officials, whether or not they amounted to a crime."); McClatchy Newspapers v. Superior Court, 209 Cal. Rptr. 598, 604 (1984); Wood v. Hughes, 9 N.Y.2d 144, 162, 173 N.E.2d 21, 31, 212 N.Y.S.2d 33, 46 (1961) (Froessel, J., dissenting) ("At common law, grand juries freely exercised the power to make presentments or reports . . . ."), superseded by statute as stated in In re Report of August-September 1983 Grand Jury III, Term IX, Suffolk County, New York, 103 A.D.2d 176, 479 N.Y.S.2d 226 (1984); Kuh, The Grand Jury "Presentment": Foul Blow or Fair Play?, 55 Colum. L. Rev. 1103, 1109-10 (1955) (tracing historical com- 
However, there is substantial disagreement on whether the grand jury should continue to have the common law $^{7}$ or statutory ${ }^{8}$ authority to

mon law grand jury report); Comment, Constitutional Law-Judicial Powers-Legality of the Grand Jury Report, 52 MicH. L. REv. 711, 721 (1954) (noting strong evidence that English common law juries made reports without charging a crime).

7 In 1955, one commentator concluded that the grand jury's reporting authority exists "in the shadow of illegality." Kuh, supra note 6, at 1103. That observation still holds true today. In the absence of unambiguous constitutional or statutory authorization, numerous state courts have held that the grand jury may not reveal official misconduct other than by initiating a prosecution. See, e.g., Ex parte Burns, 261 Ala. 217, 222, 73 So. 2d 912, 915 (1954); State ex rel. Brautigam v. Interim Report of Grand Jury, 93 So. 2d 99, 102 (Fla. 1957) (per curiam), superseded by statute as stated in Kelly v. Sturgis, 453 So. 2d 1179 (Fla. Dist. Ct. App. 1984); Bennett v. Kalamazoo Circuit Judge, 183 Mich. 200, 212, 150 N.W. 141, 144 (1914); Hughes, 9 N.Y.2d at 153,173 N.E.2d at 25, 212 N.Y.S.2d at 38-39; State v. Bramlett, 166 S.C. 323, 334, 164 S.E. 873, 877 (1932); In re Report of Grand Jury, 123 Utah 458, 467-71, 260 P.2d 521, 526-27 (1953). For additional cases, see 1 S. BEALE \& W. Bryson, Grand JURY LAW AND PRACTICE $\S 3: 03$ (1986).

The United States Supreme Court has never specifically addressed the scope of the grand jury's reporting authority. But see Hannah v. Larche, 363 U.S. 420, 449 (1960) ("T The grand jury merely investigates and reports. It does not try."); Costello v. United States, 350 U.S. 359, 362 (1956) (The grand jury was "brought to this country by the early colonists and incorporated in the Constitution by the Founders. There is every reason to believe that our constitutional grand jury was intended to operate substantially like its English progenitor."). Decisions by lower federal courts are divided on whether the grand jury can take any action critical of an identified person without returning an indictment. See generally June, 1972 Report, 370 F. Supp. at 1222-26 (collecting authorities); Annotation, Authority of Federal Grand Jury to Issue Indictment or Report Charging Unindicted Person with Crime or Misconduct, 28 A.L.R. FED. 851, 860-64 (1976) (collecting cases on authority of grand jury to accuse persons of crime without indicting).

The American Bar Association takes the position that the "grand jury should not issue any report which singles out persons to impugn their motives, hold them up to scorn or criticism or speaks of their qualifications or moral fitness to hold office or position." American Bar Association GRand JURy Policy and Model Act 4 (1982). However, the Association also emphasized that it was "not proposing that . . . grand jury reports be proscribed from commenting on the job that an office holder is performing; but such reports should not condemn character alone." Id. at 8 .

${ }^{8}$ In some states the grand jury's authority to issue reports that reveal official misconduct is precluded by statute. See Colo. Rev. STaT. § 16-5-205(4) (1978) (report shall not be used except to exonerate); LA. CoDe Crim. Proc. ANN. art. 444 (West 1967) (official comment stating that art. 444(A) "continues the prohibition against the making of general reports"); OKLA. STAT. ANN. tit. 22, \& 346 (West 1969) (permitting reports of public office, but prohibiting the charging of an individual with misconduct in order to preserve a person's right to confront her accusers); UTAH CODE ANN. § 77-11-11 (1982) (permitting reports recommending changes in government practices but prohibiting criticism of any person unless an indictment has been returned); WASH. REv. CODE ANN. $\$ 10.27 .160$ (1980) (permitting reports on broad issues of public policy that "do not identify or criticize any individual").

A few states authorize the grand jury to report publicly on official misconduct without initiating a prosecution. See CAL. Penal CoDE $\S 930$ (West 1985) (comments concerning unindicted person not privileged); FLA. STAT. ANN. $§ 905.28$ (West 1985) (report relating to individual may not issue until individual furnished a copy and is afforded 15 days to file motion to repress or to expunge); N.J. R. CRIM. PRAC. 3:6-9 
reveal official misconduct other than through an indictment.

On the one hand, a grand jury report ${ }^{9}$ that reveals official misconduct has been compared to a "foul blow" and a "hit and run motorist," since it may unjustly damage a public official's reputation without providing a forum for response. ${ }^{10}$ Critics of the reporting authority contend

(grand jury may make report censuring public official when official is an intimate part of deprecated public affairs); N.Y. CRIM. Proc. LAw § 190.85-.90 (McKinney 1982 \& Supp. 1987) (authorizing report without indictment); 42 Pa. Cons. STat. ANN. $\S 4552$ (Purdon 1981) (authorizing reports critical of unindicted individuals but allowing judge discretion to permit individual to file a response); VA. Code ANN. $\S 19.2-191$ (1983) (authorizing indictment or report on "any condition which involves or tends to promote criminal activity"); see also Irwin v. Murphy, 129 Cal. App. 713, 716-17, 19 P.2d 292, 293 (1933) (discussing California statute); Miami Herald Publishing Co. v. Marko, 352 So. 2d 518, 521 (Fla. 1977) (discussing Florida statute). Other states permit the grand jury to reveal official misconduct by initiating a removal action against specified public officials. See infra notes 261-72 and accompanying text.

In 1970, Congress authorized special grand juries that investigate organized crime to report on noncriminal misconduct by a limited category of government officials and employees, but did not define the reporting authority of other federal grand juries. See 18 U.S.C. § 3333 (1982); see also infra note 95. During the House debate on the reporting statute, one of its sponsors noted that it was not "intended to restrict or in any way interfere with the right of regular Federal grand juries to issue reports as recognized by judicial custom and tradition." June, 1972 Report, 370 F. Supp. at 1224 n.19 (remarks of Rep. Poff).

- Grand juries occasionally exercise the public reporting function by issuing documents referred to as presentments. See, e.g., In re Lundy, 208 Misc. 833, 839, 148 N.Y.S.2d 658, 663 (Sup. Ct. 1955). In the grand jury's early development, a presentment was a criminal charge initiated by the grand jury on its own knowledge. $4 \mathrm{~W}$. Blackstone, Commentaries *298. Today, the use of a grand jury presentment to initiate a criminal prosecution is obsolete in most jurisdictions. See Ex parte Faulkner, 221 Ark. 37, 40, 251 S.W.2d 822, 823 (1952); Kuh, supra note 6, at 1102-03 n.1; Dession \& Cohen, The Inquisitorial Functions of Grand Juries, 41 YALE L.J. 687, 705-06 (1932).

To avoid confusion between the generally obsolete use of a presentment to initiate a criminal prosecution and the use of a presentment to perform the reporting function, this Article refers to any grand jury document used to reveal official misconduct without initiating a prosecution as a report.

${ }^{10}$ A [report] is a foul blow. It wins the importance of a judicial document; yet it lacks its principle attributes-the right to answer and to appeal. It accuses, but furnishes no forum for a denial. No one knows upon what evidence the findings are based. An indictment may be challenged-even defeated. The [report] is immune. It is like the "hit and run" motorist. Before application can be made to suppress it, it is the subject of public gossip. The damage is done. The injury it may unjustly inflict may never be healed.

People v. McCabe, 148. Misc. 330, 333, 266 N.Y.S. 363, 367 (Sup. Ct. 1933), superseded by statute as stated in In re Report of August-September, 1983 Grand Jury III, Term IX, Suffolk County, New York, 103 A.D.2d 176, 479 N.Y.S.2d 226 (1984); see also Brautigam, 93 So. 2d at 102 (report is "no less repugnant to traditions of fair play than lynch law"); Bennett, 183 Mich. at 212, 150 N.W. at 144 (report "offends every one's [sic] sense of fair play").

It has been noted that some of the strongest judicial criticisms of the fairness of the reporting function appear in decisions written during the McCarthy era. See $1 \mathrm{~S}$. BEALE \& W. BRYSON, supra note 7, $\S 3: 03$. Indeed, the leading federal case disap- 
that the public is unable to distinguish between a grand jury report that reveals noncriminal official misconduct and an indictment that initiates a criminal prosecution. ${ }^{11}$ As a result, the report has been characterized as a threat to the public official's right to due process of law because it denies the procedural safeguards of a criminal prosecution, yet results in the same harm to reputation as a criminal accusation. ${ }^{\mathbf{1 2}}$

On the other hand, proponents of the grand jury's reporting authority argue that such reports promote democracy by publicly exposing government wrongdoing. ${ }^{13}$ Moreover, the grand jury report has been praised as a device to hold public officials accountable under a stricter standard of conduct than that required by the criminal law. ${ }^{14}$ Thus, the report has been called "one of the most valued and treasured restraints upon tyranny and corruption in public office."15

The controversy that surrounds the reporting function was recently revived when a state grand jury in Alaska issued a public report that recommended that the legislature initiate impeachment proceedings against the Governor. ${ }^{16}$ That an Alaska grand jury issued a report crit-

proving of grand jury reports, In re United Elec. Radio \& Mach. Workers, $111 \mathrm{~F}$. Supp. 858 (S.D.N.Y. 1953), involved a 1952 report prepared under the direction of Roy Cohn, who would soon gain notoriety as chief counsel to Senator McCarthy.

The report in Electrical Workers accused union officials of communist party membership and activities. It is uniformly held that the grand jury lacks the authority to report on misconduct by private persons. See supra note 5 . No doubt recognizing that it could not use the reporting function to criticize private persons, the grand jury did not identify the criticized union officials in its report. However, the day after the report was released, the grand jury foreman and prosecutor leaked the names of the officials to the press. Electrical Workers, $111 \mathrm{~F}$. Supp. at 861 . The report revealed that the union officials had claimed the fifth amendment in testimony before the grand jury and concluded that affidavits they had previously filed with the National Labor Relations Board attesting to noncommunist party membership were not "'worth the paper they are written on." "Id. at 860 . In his opinion expunging the report, District Judge Weinfeld labeled as "highly improper" the prosecutor's questioning of grand jury witnesses as to their "belief in a Supreme Being, baptism, their particular religious faith, the length of adherence to it, atheism and agnosticism." Id. at 869-70.

Considering that the report in Electrical Workers alleged misconduct by private citizens rather than public officials, the method used to identify the criticized union officials, and other objectionable prosecutorial tactics used during the grand jury's investigation, it is not surprising that the report received a hostile reaction in the district court. For a perspective on the issues raised by Electrical Workers and Roy Cohn's role in the grand jury investigation, written by one of the authors of the union's brief seeking expungement of the report, see A. KinOy, RightS ON TRIAL: THE ODYSSEY OF A PEOPLE'S LAWYER 97-113 (1983).

11 See infra text accompanying note 88 .

12 See infra text accompanying note 91 .

13 See infra text accompanying note 54 .

14 See id. 1946).

16 Public Papers of Thomas E. Dewey 140-41 (State of New York pub.

16 Report of the Grand Jury Concerning the Investigation Conducted into the Fairbanks Consolidated State Office Lease with the 


\section{icizing a public official is not in itself particularly noteworthy. ${ }^{17}$ The}

Fifth Avenue Center 18 (Sup. Ct. Alaska July 1, 1985) [hereinafter Alaska ImPEACHMENT REPORT].

This recommendation was the culmination of the grand jury's investigation into the award of a $\$ 10$ million lease of state owned office space. The investigation centered on allegations that the Governor's office had manipulated the state's competitive bidding process to ensure that the lease was awarded to a partnership that included a major gubernatorial campaign fundraiser. See id. at 21-67 (summary of evidence). Although the grand jury did not return any indictments, its report concluded that the Governor's administration "has not best served the interests of the public and is unfit to fulfill the inherent duties of public office." Id. at 2 (emphasis in original). The report summarized the evidence heard by the grand jury, quoted extensively from key portions of the Governor's grand jury testimony, and concluded that in his testimony the Governor showed "extraordinarily poor recollection" and "a lack of candor and a disrespect for the laws of this state." Id. at 13-14. The Rules Committee of the Alaska State Senate responded to the report by holding impeachment hearings. See Inquiry into the Report of the Grand Jury of the First Judicial District, Superior Court, State of Alaska Dated July 1, 1985 Before the Senate Rules Committee of the Alaska State Legislature (transcript of proceedings, July 22, 1985 through August 3,1985) [hereinafter Senate Impeachment Transcript].

The committee did not, however, adopt articles of impeachment. It adopted a "clear and convincing evidence" standard to find an impeachable offense. See Alaska S.J., 14th Legis., 1st Spec. Sess., at 1490 (Aug. 5, 1985) (Senate Rules Committee, Inquiry into the July 1, 1985 Grand Jury Report). At the conclusion of its hearings, the Committee adopted a resolution and report which found that there was substantial, but not clear and convincing evidence, that the Governor committed an impeachable offense. Alaska S. Res. 7, 14th Legis., 1st Spec. Sess. (Aug. 5, 1985) (adopting section of report and resolution of Senate Rules Committee, Alaska S.J., 14th Legis., 1st Spec. Sess., at 1491 (Aug. 5, 1985)).

Several senators challenged the legality of the report that triggered the impeachment inquiry. See, e.g., Alaska S.J., 14th Legis., 1st Spec. Sess., at 1500 (Aug. 5, 1985) (Senate Floor Statement-Due Process: Rights of the Accused, Statement of Sen. Ferguson) ("While I find nothing wrong with . . . a report containing recommendations concerning the public welfare and safety, I find the legal basis of allowing a grand jury to issue a report naming a public official without returning an indictment to be deliberately or unprofessionally negligent."); see also infra note 19 (remarks of Sen. Ziegler).

The Alaska Senate took no action on the report adopted by the committee but amended the Resolution to remove all language critical of the Governor. ALASKa S.J., 14th Legis., 1st Spec. Sess., at 1499, 1505-06 (Aug. 5, 1985).

The Alaska report is discussed in detail infra at text accompanying notes 167-227.

${ }_{17}$ Grand juries in Alaska frequently issue public reports pursuant to their state constitutional authority "to investigate and make recommendations concerning public welfare and safety." ALASKA CoNST. art. I, § 8. This constitutional provision is unique to Alaska and was cited by the grand jury as authorizing its report. See AlaskA IMPEACHMENT REPORT, supra note 16, at 4. Between 1961 and 1971, Alaska grand juries issued 28 reports on a wide variety of topics, including overcrowding in state prisons, sentences for criminal defendants, drug abuse by minors, and the use of electronic listening devices. See Memorandum from Don G. Bauermeister, Court Rules Attorney, to Arthur H. Snowden, II, Administrative Director, at 80-91 (Sept. 30, 1985) (Alaska Court System; Criminal Rule 6: Grand Jury Procedure) (on file with the University of Pennsylvania Law Review). Moreover, two previous reports had criticized public officials and recommended their discipline or removal. See Memorandum from Daniel W. Hickey, Chief Prosecutor, to Harold M. Brown, Attorney General, at 28-29 (Aug. 20, 1985) [hereinafter Memorandum of Chief Prosecutor] (discussing two grand jury reports that recommend discipline or removal of correctional officers). Reports is- 
significance of the report, however, is that it criticized the Governor and called for the initiation of impeachment proceedings. ${ }^{18}$ It is therefore not surprising that the report was controversial and that the grand jury was criticized for "passing the buck" to the legislature by recommending impeachment instead of indicting the Governor. ${ }^{19}$

The concern that the Alaska grand jury passed the buck to the legislature did not directly challenge the grand jury's authority to report on the Governor's noncriminal misconduct. ${ }^{20}$ Indeed, such author-

sued since 1971 are summarized in Alaska Judictal Council, The Investigative Grand JURY IN AlASKa 44-48 (1986). For a detailed review of the reporting authority of Alaska grand juries, see Note, The Reportorial Power of the Alaska Grand Jury, 3 Alaska L. Rev. 295 (1986).

18 Although this was apparently the first time that a grand jury report called for the initiation of impeachment proceedings against a governor, at least two reports have recommended impeachment of other public officials. See In re Report of Ormsby County Grand Jury, 74 Nev. 80, 82, 322 P.2d 1099, 1100 (1958) (urging impeachment of surveyor general); $I n$ re the Presentment Made to the Superior Court by the Camden County Grand Jury on or About October 11, 1951, 10 N.J. 23, 48, 89 A.2d 416, 432 (1952) (citing a report issued in 1903 recommending impeachment of a justice of the peace); see also 3 A. Hinds, Precedents of the House of Representatives OF THE UNITED STATES $§ 2488$ (1907) (presentment against territorial judge forwarded to House of Representatives for consideration of possible impeachment proceedings).

${ }^{19}$ See, e.g., Alaskans Debate Grand Jury Process, Report, Juneau Empire, July 16, 1985, at 1, col. 1, 1, col. 2 (remarks of Al Baffone, Sr., business manager and secretary treasurer of Public Employees Local 71 in Anchorage) (" 'I can't understand why the grand jury didn't fulfill their obligations to the state by indicting the governor if he committed something wrong to the extent that he deserved to be impeached

,"); Senators Study Grand Jury Testimony, Juneau Empire, July 12, 1985, at 1, col. 1, 14, col. 4 (remarks of State Sen. Ray) ("If there was an indictable offense why didn't the jury simply indict.... ?" ").

Moreover, both the grand jury and the prosecutor who presented the case were accused of acting illegally. See, e.g., Senate Impeachment Transcript, supra note 16, at 123 (July 22, 1985) (statement of Phillip Lacovara, counsel for the Governor during the impeachment hearings) (asserting that the grand jury acted illegally in issuing its report); Full Alaska Senate to Question Governor Today, N.Y. Times, July 26, 1985, at A8, col. 3 (remarks of State Sen. Robert Ziegler) ("This grand jury was led down a path where it violated every sense of fairness and decency. It embarked on courses of action that are unethical and illegal."); Alaskans Debate Grand Jury Process, Report, supra, at 1, col. 2 (remarks of Al Baffone, Sr.) ("Frankly, under the circumstances, it appears to me that the grand jury ought to be indicted for wrongdoing." ").

After the impeachment proceedings were concluded, the Alaska Senate's chief counsel during the inquiry, Sam Dash, agreed that the grand jury acted improperly in issuing its report. See Impeachment Adversaries Say Jury Wrong in Issuing Report, Fairbanks Daily News-Miner, Aug. 9, 1985, at 1, col. 1, 1, col. 2.

${ }^{20}$ It has generally been assumed that the purpose of a grand jury report is to reveal official misconduct falling short of a crime. The leading case that supports the grand jury's reporting authority, for example, refers to it as a device to reveal "official acts and omissions that fall short of criminal misconduct and yet are not in the public interest." Camden, 10 N.J. at 66, 89 A.2d at 444; see also 18 U.S.C. $\S 3333(\mathrm{a})(1)$ (1982) (limiting the reporting authority of special grand juries to noncriminal conduct relating to organized crime); N.J. R. CRIM. PRAC. 3:6-9(c) (defining the grand jury's authority to report on official misconduct as limited to the ability to reveal "non-crimi- 
ity is a valuable and necessary device in a democratic society. Instead, concern arose from the perception that, at times, the report accused the Governor of criminal misconduct and, moreover, suggested that the grand jury had chosen not to indict because the jurors viewed their report as a preferable alternative to prosecution of the Governor. ${ }^{21}$ An analysis of the interests expressed by the grand jury for this preference, coupled with the need for judicial review of a report before release, will reveal, however, that those interests are not served by the use of a report as an alternative to a prosecution. ${ }^{22}$

This Article is divided into three parts. Part I briefly traces the common law origins of the grand jury's reporting function. Part II examines four reports that reveal violations of the public trust and identifies and discusses the competing interests implicated by the reporting function. Part III reviews those interests and suggests the appropriate scope of the grand jury's authority to reveal official misconduct without returning an indictment. Although the Article concludes that grand jury reports can continue to serve an important function by identifying violations of the public trust that are not indictable, it rejects the use of a public report as an alternative to a prosecution.

nal" misconduct). Reports that suggest that a public official has committed a crime have been held to be improper. See In re Jordan, 439 F. Supp. 199, 202 (S.D. W. Va. 1977); Biglieri v. Washoe County Grand Jury Report Dated March 15, 1976, 95 Nev. 696, 698, 601 P.2d 703, 704 (1979); In re the Presentment Made to the Superior Court by the Camden County Grand Jury, 1959 Term, First Stated Session, on or About June 7, 1960, 34 N.J. 378, 389-91, 169 A.2d 465, 471-72 (1961). See also In re Report of Grand Jury, 152 Fla. 154, 159, 11 So. 2d 316, 319 (1943) (striking language in report that grand jury decided not to indict in part because conviction appeared unlikely), superseded by statute as stated in Kelly v. Sturgis, 453 So. 2d 1179 (Fla. Dist. Ct. App. 1984).

${ }^{21}$ See infra notes 226-27 and accompanying text.

${ }^{22}$ Indeed, some courts have held that a report should not be used as an alternative to a prosecution. See In re Messano, 16 N.J. 142, 147, 106 A.2d 537, 539 (1954) (a grand jury may not issue a report "if it appears that a crime has been committed for which an indictment may be had"); In re Investigation into the Hamilton Township Bd. of Educ., 205 N.J. Super. 248, 250, 500 A.2d 744, 745 (App. Div. 1985) ("Prior to [preparing a report] . . . censuring a public official for abuse of his office, the Grand Jury must resolve that the evidence before it is insufficient or lacking for a criminal indictment against him for the same wrongdoing."); Kuh, supra note 6, at 1126-27 ("recognition of the difficulties of conviction, even though technically a legal case can be made out and the accusatory body convinced of guilt, should not induce accusation by report"). But see In re Second Report of the November, 1968 Grand Jury, 26 N.Y.2d 200, 213, 257 N.E.2d 859, 866, 309 N.Y.S.2d 297, 307 (1970) (Brietel, J., dissenting) (" $t$ ] he report may be submitted not only in the event that no criminal conduct has been found, but also when the grand jury, in the exercise of its broad discretion, chooses not to file an indictment or criminal information, yet feels obliged to report concerning noncriminal misconduct in office"), superseded by statute as stated in In re Report of August-September, 1983 Term Grand Jury III, Term IX, Suffolk County, New York, 103 A.D.2d 176, 479 N.Y.S.2d 226 (1984). 


\section{Common Law ORigins of the Reporting Function}

The grand jury serves as both a sword and a shield..$^{23}$ As a sword, the grand jury provides the investigatory resources often required to initiate a prosecution; as a shield, it protects the innocent from unjustified prosecution. ${ }^{24}$ It is generally agreed, however, that in its development the grand jury had sharpened its sword to a fine point long before it acquired its shield. ${ }^{25}$ Although a comprehensive discussion of the historical development of the grand jury is beyond the scope of this Article, a brief review is necessary to place the emergence of the grand jury's reporting authority in perspective.

Most authorities trace the origins of the grand jury to the reign of Henry II and the publication of the Assize of Clarendon in $1166 .{ }^{26}$ During the first five hundred years of its existence, the grand jury served exclusively as a sword for the Crown to consolidate power and to prosecute suspected lawbreakers. ${ }^{27}$ The first evidence of the grand jury functioning as a shield for the accused does not appear until 1681, when grand juries in the Colledge and Shaftesbury cases refused to in-

${ }^{23}$ See United States v. Calandra, 414 U.S. 338, 343 (1974) (The grand jury's "responsibilities continue to include both the determination whether there is probable cause to believe a crime has been committed and the protection of citizens against unfounded criminal prosecutions."); United States v. Roth, 777 F.2d 1200, 1202 (7th Cir. 1985) ("[T]he grand jury is as a matter of fact an investigative arm of the prosecutor's office, as a matter of liberty it is a protection for the liberty of the citizen."); In re Presentment of Special Grand Jury Impaneled January, 1969, 315 F. Supp. 662, 671 (D. Md. 1970) ("The Grand Jury is both a sword and a shield."(citation omitted)).

24 See generally $1 \mathrm{~W}$. Lafave \& J. Israel, Criminal Procedure $\S 8.1, .3$ (1984) (analyzing the dual functions of the grand jury and the investigative advantages that the system affords).

${ }^{25}$ See infra text accompanying notes 27-28.

${ }^{26}$ See 1 W. Lafave \& J. IsRael, supra note 24, § 8.2(a); T. PlunknetT, A Concise History of The Common Law 112-13 (5th ed. 1956); 1 F. Pollock \& F. Maitland, The History of ENGlish Law 151-53 (2d ed. 1898); Helmholz, The Early History of the Grand Jury and the Canon Law, 50 U. CHI. L. REv. 613, 613 (1983). But see Schwartz, Demythologising the Historic Role of the Grand Jury, 10 AM. CRIM. L. REv. 701, 705-07 (1972) (tracing the modern day grand jury to the signing of the Constitutions of Clarendon in 1164).

The Assize authorized "twelve most lawful men" to be put under oath and, after they were questioned by justices of the peace and sheriffs, directed to accuse anyone "believed to be a robber, murderer, thief, or a receiver of such." Assize of Clarendon, Chapter I, reprinted in T. Plunknetr, supra, at 112-13. See generally 2 F. PoLLOCK \& F. MAITLAND, supra, at 641-48 (discussing the composition of grand juries and procedures for presentments and indictments).

If the accusation was based on the grand jurors' personal knowledge, the formal charge was called a presentment. See supra note 9. The Crown initiated an accusation and submitted it to the grand jury in the form of an indictment, endorsed by the grand jury as either a "true bill" if charges were justified, and "ignoramus" if not. See S. WebB \& B. WebB, English Local, Government from the Revolution to the Municipal Corporations ACT: The Parish and the County 448 (1906).

${ }^{27}$ See Kuh, supra note 6, at 1106-07; Schwartz, supra note 26, at 709-10. 
dict supporters of the Protestant cause accused of treason by King Charles II. ${ }^{28}$

Around the same time that the Colledge and Shaftesbury grand juries exercised a degree of independence from the Crown, other English grand juries began to assume responsibilities beyond their original role as a criminal accusatory body. The grand jury began to act "as a sort of 'third estate' of the shire, or county 'House of Commons,' giving the opinion of the county on matters of public concern . . ."29 The presentment, originally a form of criminal accusation, ${ }^{30}$ was adapted by the grand jury to report publicly on a variety of noncriminal subjects.

The use of the grand jury report expanded over time. English grand juries in the late seventeenth and early eighteenth centuries used it to comment on matters of community concern and frequently complained that counties were not properly maintaining bridges and prisons. ${ }^{31}$ Significantly, reports began to question the conduct of public officials. ${ }^{32}$ The expanding role of the grand jury during this period is even more thoroughly documented in colonial America, where, in addition to their accusatory function, "[g]rand juries acted in the nature of local assemblies: making known the wishes of the people, proposing new laws, protesting against abuses in government, performing administrative tasks, and looking after the welfare of their communities."

${ }^{28}$ See Trial of Stephen Colledge, 8 Howell State Trials 549 (1681) (transcript of proceedings); The Earl of Shaftesbury's Trial, 8 Howell State Trials 759 (1681) (transcript of proceedings). The Colledge and Shaftesbury cases are examined in detail in Schwartz, supra note 26 , at $710-21$. While the cases have been cited as examples of how the grand jury can act "as a bulwark against the oppression and despotism of the Crown," In re Russo, 53 F.R.D. 564, 568 (C.D. Cal. 1971), Professor Schwartz concludes that the voluntary exile of Shaftesbury to avoid a pending indictment "epitomizes the impotence of the grand jury in the face of a determined exercise of executive power...." Schwartz, supra note 26, at 719-20.

${ }^{29} \mathrm{~S}$. WEBB \& B. WEBB, supra note 26 , at 448.

so See supra note 9.

$3110 \mathrm{~W}$. Holdsworth, A History of ENGLish Law 148 (1938). Holdsworth notes that this use of the presentment was apparently so routine that parliament provided that no money was to be spent on the repair of bridges, jails, prisons, or houses of correction unless the need was first established by a grand jury presentment. See id.; see also S. WEBB \& D. WEBB, supra note 26, at 448-52 (history of the financial function of the grand jury). Grand juries also reported that the law requiring signposts at crossroads was not being enforced, causing "great inconvenience and damage [to] Her Majesty's liege people." Id. at 454. At times the grand jury's complaint took the form of a petition to parliament. Id. at 455-56.

32 For instance, a coroner was presented for "vexing" a jury when it failed to return the verdict he had requested, and several constables were criticized for not enforcing laws that regulated the distribution of corn and the control of beggars. See S. WEBB \& D. WEBB, supra note 31, at 453-54.

${ }^{33}$ R. Younger, The People's Panel: The Grand Jury in the United States, 1634-1941, at 2 (1963). See also L. Glark, The Grand Jury 14-15, 17 (1975) (discussing the "quasi-legislative" functions performed by colonial grand juries); 
Despite these diverse functions, the primary role of the grand jury remained its criminal accusatory function. As the common law grand jury began to develop its shield role, however, it simultaneously expanded its responsibilities in many other directions. One new responsibility was to become a self-appointed citizens' watchdog over government. As grand juries turned their attention to the performance of government, they would discover deficiencies and want to report their findings publicly. When a grand jury criticized a public official for causing or tolerating those deficiencies, it was not initiating a prosecution, but instead ensuring that the official's conduct would come under public review. Nevertheless, the official was accused of misconduct by the same body that initiated criminal prosecutions. In the public's mind, the distinction between a public report that revealed official misconduct and an indictment that initiated a prosecution may have become blurred. The remainder of this Article focuses on whether the modern grand jury should have the authority to reveal violations of the public trust without initiating a prosecution.

\section{IDENTIFYING THE COMPETING INTERESTS}

Grand juries in New Jersey and New York were particularly ac-

In re Report and Recommendation of June 5, 1972 Grand Jury Concerning Transmission of Evidence to the House of Representatives, 370 F. Supp. 1219, 1222-23 (D.D.C.) (grand jury is "a great channel of communication between those who make and administer the laws, and those for whom the laws are made and administered. . . . They may suggest publick improvements, and the modes of removing publick inconveniences: they may expose to publick inspection, or to publick punishment, publick bad men, and publick bad measures." (citation omitted) (quoting remarks made in 1791 by James Wilson, signer of Declaration of Independence and Constitution and Supreme Court Justice)), affd sub nom. Haldeman v. Sirica, 501 F.2d 714 (D.C. Cir. 1974).

For example, grand juries in Virginia supervised road construction, Pennsylvania grand juries inspected public bridges and jails, while their counterparts in Maryland surveyed land in boundary disputes. See R. YoungER, supra, at 11-16. In 1700, a New Jersey grand jury recommended a head tax on livestock and slaves to pay off the county debt. Id. at 13. See also In re the Presentment Made to the Superior Court by the Camden County Grand Jury on or About October 11, 1951, 10 N.J. 23, 41-44, 89 A.2d 416, 427-28 (1952) (giving additional examples of noncriminal reports issued by colonial New Jersey grand juries). In addition, a New York grand jury in 1681 proposed that the colony be permitted to have an elected assembly. See R. YounGER, supra, at 14; see also J. GOEBEL \& T. NAUghton, LAW ENFORCEMENT IN ColoNIAL NEW YORK 361-63 (1944) (citing additional examples of noncriminal reports issued by colonial New York grand juries). In Massachusetts a grand jury once questioned the right of the Governor and his assistants to sell land to certain persons; in Annapolis a grand jury protested against the refusal of city officials to account for lottery proceeds and the failure of city council members to attend meetings; and in Charleston grand juries complained about the disorderly behavior of the town watch and the failure of city officials to regulate town markets. See R. Younger, supra, at 7, 18. 
tive in issuing public reports during the first half of this century. The legality of that practice, however, was not decided by the New Jersey Supreme Court until 1952, in In re the Presentment Made to the Superior Court by the Camden County Grand Jury on or About October $11,1951,{ }^{34}$ and was only addressed by the New York Court of Appeals in 1961, in Wood v. Hughes. ${ }^{35}$ In Camden, the court praised grand jury reports that identify official misconduct and held that New Jersey grand juries retained their common law reporting authority ${ }^{36}$ In Hughes, the court characterized grand jury reports as a threat to individual freedom and held that, in the absence of clear statutory authorization, New York grand juries could not reveal official misconduct other than through an indictment. ${ }^{37}$

This part of the Article identifies and discusses the competing interests implicated by the reporting function and is divided into four sections. The first two sections review and critique the contrasting judicial responses of the Camden and Hughes decisions to grand jury reports that reveal official misconduct that is not subject to prosecution. The remaining sections discuss two grand jury investigations and reports that concern criminal misconduct. These reports highlight the issue of whether a report should be used as an alternative to prosecuting a public official for a criminal violation of the public trust. The third section reviews the grand jury investigation and report that transmitted key evidence to the House Judiciary Committee concerning President Nixon's involvement in the Watergate cover-up. In In re Report and Recommendation of June 5, 1972 Grand Jury Concerning Transmission of Evidence to the House of Representatives, ${ }^{38}$ District Judge Sirica decided to transmit the grand jury report to the House Judiciary Committee. Judge Sirica's reasons for doing so highlight the apparent differences between the Watergate report and the report reviewed in the fourth section, the Alaska Impeachment Report.

\section{A. Camden: Highlighting the Public Interest and the Lack of Forum Objection}

The report at issue in Camden resulted from a grand jury investi-

3410 N.J. 23, 89 A.2d 416 (1952).

so 9 N.Y.2d 144, 147, 173 N.E.2d 21, 21-22, 212 N.Y.S.2d 33, 34 (1961), superseded by statute as stated in In re Report of August-September, 1983 Grand Jury III, Term IX, Suffolk County, New York, 103 A.D.2d 176, 479 N.Y.S.2d 226 (1984).

${ }^{38}$ See infra text accompanying notes 39-54.

${ }^{37}$ See infra text accompanying notes 79-91.

38370 F. Supp. 1219 (D.D.C.), aff'd sub nom. Haldeman v. Sirica, 501 F.2d 714 (D.C. Cir. 1974). 
gation into a jail escape. ${ }^{39}$ At the conclusion of the investigation the grand jury indicted the undersheriff and several jail guards on charges of misconduct in office, false swearing, and conspiracy. ${ }^{40}$ The indictments were accompanied by a report that listed numerous irregularities in the management of the jail, recommended legislative and administrative changes, and criticized the sheriff for his job performance and lack of cooperation during the investigation. ${ }^{41}$ The sheriff, who was not indicted, moved to expunge those portions of the report that he argued were defamatory. ${ }^{42}$ The lower court denied the motion, the sheriff appealed to the appellate division, and on its own motion the supreme court removed the case for consideration. ${ }^{43}$

Writing for the court, Chief Justice Vanderbilt surveyed numerous reports published by New Jersey grand juries between 1866 and 1932.4 The reports touched on virtually every aspect of community life and provide a rich chronicle of the major concerns of the period. The reports focused primarily on the quality of governmental services, particularly those provided by fire and police departments, jails, hospitals, and asylums. ${ }^{45}$ The reports typically included findings on the adequacy of governmental services ${ }^{46}$ and, in some cases, proposed laws to address problems uncovered during the grand jury investigation. ${ }^{47}$ When the grand jury found a service to be inadequate, its report offered suggestions for improvement ${ }^{48}$ and sometimes criticized public officials for

${ }^{39}$ Camden, 10 N.J. at 26,89 A.2d at 417.

10 Id. at 26,89 A.2d at 418 .

11 Id. at $27-31,89$ A.2d at $418-21$.

42 Id. at $31-32,89$ A.2d at $421-22$. An official who believes that the grand jury has acted improperly has two procedures through which to challenge the legality of a grand jury report. First, the official may sue the members of the grand jury, or even the district attorney, for libel. The theory behind a libel action is that a grand jury report is "extra-judicial," and hence not privileged. See Comment, supra note 6, at 713-14. It is difficult for the public official to prevail in such a case. See Comment, The Propriety of the Grand Jury Report, 34 TEx. L. REv. 746, 752 (1956).

The most common attack on a grand jury report is a motion to expunge. See United States v. Briggs, 514 F.2d 794, 801-04 (5th Cir. 1975) (motion to expunge name of unindicted coconspirator).

4 Camden, 10 N.J. at 32,89 A.2d at 422 .

44 Id. at $44-59,89$ A.2d at 429-39.

15 See id.

46 For example, a 1909 report noted the lack of adequate fire fighting equipment in Newark. See id. at 54, 89 A.2d at 436.

47 For example, a 1905 report concluded that there was a significant number of false registrations during a recent election and recommended enactment of a registration law similar to one that had been adopted recently in Pennsylvania. See id. at 49-50, 89 A.2d at $432-33$.

48 For example, a 1904 report criticized the ambulance service offered by Newark and recommended that each private hospital in the city be provided with an ambulance at public expense. See id. at 49,89 A.2d at 432. 
their role in creating or tolerating governmental deficiencies. ${ }^{49}$ Occasionally, the grand jury recommended the removal of the criticized official. $^{.0}$

After surveying the history of grand jury reports in New Jersey, Justice Vanderbilt concluded that the framers of the most recent state constitution intended to authorize reports concerning "public affairs as they had been known in New Jersey from earliest colonial times." Turning to the challenged report, he concluded that, since it outlined irregularities in jail management, it was "so clearly in the public interest that there can be no doubt of the duty of the grand jury to make it or of the assignment judge to receive and file it." ${ }^{\prime \prime 2}$

Although a portion of the report challenged in Camden was subsequently disapproved by the court, ${ }^{53}$ Chief Justice Vanderbilt's sweep-

49 For example, a 1932 report found that the county board of elections, commissioner of registration, superintendent of elections, and sheriff had failed to safeguard an election. See id. at 59, 89 A.2d at 439.

so Three reports issued between 1903 and 1910 show just how broadly New Jersey grand juries viewed their public reporting function in connection with investigations into misconduct by public officials. In one report the grand jury concluded that the superintendent and supervisor of an asylum were guilty of willful neglect of duty, expressed disapproval at their continued retention, and noted that the statute of limitations prevented it from "taking official cognizance of the nonfeasance and malfeasance in the management of the asylum." Id. at 55, 89 A.2d at 436. Another report concerned the grand jury's investigation of a factory fire in which several persons died. The grand jury criticized the captain of an engine company for not turning in an alarm promptly and concluded "that the state factory inspector and his superior could not be too strongly condemned" for not previously reporting conditions that existed at the scene of the fire. Id. at 57, 89 A.2d at 438 . In 1903, a grand jury presented a justice of the peace for gross violation of his official duties. For a reason not explained in the report, the grand jury was prevented from returning an indictment. Nevertheless, the report noted that if the grand jury could have brought criminal charges it would have done so since the justice of the peace "was guilty of malfeasance in office so vile and scandalous as to make it a disgrace to the county." Id. at 48,89 A.2d at 432 .

${ }^{81}$ Id. at 65,89 A.2d at 443 . The New Jersey Constitution provides that "[n]o person shall be held to answer for a criminal offense, unless on the presentment or indictment of a grand jury ...." N.J. ConsT. art. I, § 8. Justice Vanderbilt concluded that the debate on this provision at the Constitutional Convention of 1947 established that the drafters, by their reference to presentments, intended to authorize noncriminal rather than criminal presentments. See Camden, at 64-65, 89 A.2d at 443.

s2 Camden, at 68, 89 A.2d at 444-45.

ss In Camden, the grand jury report referred to the sheriff as "a poor witness whose testimony was evasive and lacking in cooperation" and whose "disinterest and lack of knowledge of his job . . . rates the strongest kind of moral indictment." Id. at 31-32, 89 A.2d at 421-22 (emphasis omitted). In In $r e$ the Presentment Made to the Superior Court by the Camden County Grand Jury, 1959 Term, First Stated Session, on or About June 7, 1960, 34 N.J. 378, 169 A.2d 465 (1961), the court disapproved of this portion of the report, holding that "[a] grand jury transcends its powers when it reprobates and disparages an individual on the basis of its opinion of the testimony he gave on appearance before it." Id. at 397, 169 A.2d at 475 . The Queens County Court reached a similar conclusion in In re Lundy, 208 Misc. 833, 846, 148 N.Y.S.2d 658, 669 (Sup. Ct. 1955), holding that deception in grand jury testimony "was not an act of 
ing endorsement of the reporting function continues to be the classic argument in support of that authority:

If [reports] of matters of public concern were found necessary in the public interest in the relatively simple conditions of English and colonial life three centuries ago, how much more essential are they in these days when government at all levels has taken on a complexity of organization and of operation that defies the best intentions of the citizen to know and understand it. What is not known and understood is likely to be distrusted. What cannot be investigated in a republic is likely to be feared. The maintenance of popular confidence in government requires that there be some body of laymen which may investigate any instances of public wrongdoing.

... The grand jury provides a readily available group of representative citizens of the county empowered, as occasion may demand, to voice the conscience of the community. There are many official acts and omissions that fall short of criminal misconduct and yet are not in the public interest. It is very much to the public advantage that such conduct be revealed in an effective, official way. No community desires to live a hairbreadth above the criminal level, which might well be the case if there were no official organ of public pro-

a public official in the administration of the business of his office" and therefore should not have been included in a report criticizing the official.

It will be recalled that the Alaska Impeachment Report referred to the Governor's grand jury testimony as reflecting "extraordinarily poor recollection" and "a lack of candor and a disrespect for the laws of this state." See Alaska ImPEAchment REPORT, supra note 16, at 13-14. Applying the analysis used in Part III of this Article for defining the appropriate role of the reporting function, the quoted language in the Alaska report should not have been included in the report for two alternative reasons. First, if the grand jury lacked sufficient evidence to indict for perjury, its report should not have implied that the Governor committed perjury. Second, if the grand jury believed that it could have indicted the Governor for perjury, it should not have issued a public report as an alternative to indictment. See infra notes 243-60 and accompanying text.

However, if a public official's grand jury testimony is evasive or deceptive, but not to the extent sufficient to support an indictment, a report that revealed the testimony would alert the public to the possibility that the official may be in violation of the public trust. Cf. Uniformed Sanitation Men Ass'n v. Commissioner of Sanitation, 392 U.S. 280, 285 (1968) (noting that public employees are subject to dismissal if they refuse to account for their performance of a public trust). As long as a report does not suggest that an official committed perjury before the grand jury, and the grand jury specifically exonerates the official of criminal misconduct, a report that reveals the official's deceptive testimony should be classified as within the appropriate scope of the reporting function. See infra text accompanying notes $237-42$. 
test. Such [reports] are a great deterrent to official wrongdoing. By exposing wrongdoing, moreover, such [reports] inspire public confidence in the capacity of the body politic to purge itself of untoward conditions. ${ }^{\mathbf{5 4}}$

\section{The Public Interest}

Chief Justice Vanderbilt's spirited and eloquent defense of the grand jury's common law reporting function advances two primary justifications for its retention. First, the grand jury's ability to investigate and publicly report on wrongdoing in government exposes government actions to public scrutiny, and thereby strengthens the democratic system. Because the grand jury is a "body of laymen," public confidence in the accountability of government is enhanced; ordinary citizens can review its operations. Second, the reporting function ensures that public officials are held accountable for noncriminal violations of the public trust by identifying perceived misconduct, thus allowing "the body politic to purge itself of untoward conditions." result in the imposition of a criminal sanction, it stimulates public review of the grand jury's findings and may lead to the removal, discipline, or election defeat of the criticized official. The publicity that results from a report also may deter others from violating the public trust. The grand jury report can therefore be viewed as a democratic device furthering the public's right to know about government and holding public officials accountable for noncriminal violations of the public trust. ${ }^{56}$

${ }^{54}$ Camden, 10 N.J. at $65-66,89$ A.2d at $443-44$.

so Id. at 66,89 A.2d at 444 .

Bo Similar reasoning has been followed by other courts upholding the grand jury's authority to report on the performance of public officials. See, e.g., McGlatchy Newspapers v. Superior Court, 209 Cal. Rptr. 598, 604 (Cal. App. 1985) ("The people . . . have a basic right to know about the workings of their state and local government including the activities of public officials in the performance of their official duties."); Miami Herald Publishing Co. v. Marko, 352 So. 2d 518, 523 (Fla. 1977) ("A society governed by representative officials concomitantly requires citizen review of public action. . . Implicit in the power of the grand jury to investigate and expose official misconduct is the right of the people to be informed of its findings." (footnotes omitted)); In re Report of Grand Jury, 152 Fla. 154, 159, 11 So. 2d 316, 319 (1943) (The grand jury report "is a means whereby the people participate[] directly in the administration of their business . . . ."); In re Healy, 161 Misc. 582, 594, 293 N.Y.S. 584, 597 (Sup. Ct. 1937) ("[I]t is entirely conceivable that public officials, while not guilty of criminality, may be found to be so lacking in understanding or appreciation of the duties which are part of their office that a grand jury may be discharging a very high form of public service if [it] report[s] [its] findings . . . ."). See also Wood v. Hughes, 9 N.Y.2d 144, 161, 173 N.E.2d 21, 30, 212 N.Y.S.2d 33, 45 (1961) (Desmond, C.J., dissenting) (" $[\mathrm{N}]$ othing is more hostile to the central spirit of American political philos- 
Justice Vanderbilt also surveyed alternative methods of investigating official misconduct and concluded that the grand jury's reporting function "serve[s] a need that is not met by any other procedure." The legislature, for example, has broad investigatory powers, but he noted that those powers are infrequently used and seldom examine problems of local government. ${ }^{68}$ Entrusting the grand jury with the authority to investigate and report on official misconduct, Justice Vanderbilt observed, also minimizes the possibility that the official will be unjustifiably accused because "of the care with which grand juries are selected, the secrecy with which they deliberate and the judicial control of such [reports] when they are handed to the court."

Justice Vanderbilt's conception of the grand jury was of an independent "people's panel" functioning outside of government. ${ }^{60}$ Today's grand jury, however, is more often characterized as an institution dominated by the prosecutor or as an arm of the court. ${ }^{61}$ More accurately,

ophy than to allow any public officer to suppress and bury a relevant, nonscandalous commentary on public affairs by an authorized body of citizens."), superseded by statute as stated in In re Report of the August-September, 1983 Grand Jury III, Term IX, Suffolk County, New York, 103 A.D.2d 176, 479 N.Y.S.2d 226 (1984).

${ }^{57}$ Camden, 10 N.J. at 66,89 A.2d at 443 . Additional support for the view that the grand jury is better equipped than other institutions to investigate official misconduct appears in Kuh, supra note 6, at 1118-20 (pointing out that no overseer exists to guarantee that legislative or executive committees act fairly while conducting investigations); Note, supra note 17, at 305-06 (grand juries freer from political concerns than legislature and executive committees). See also $1 \mathrm{~W}$. LAFAve \& J. IsRaEL, supra note 24 , at $\S 8.3(\mathrm{~g})$ (stating that grand jury investigations quell public suspicions of partisan influences).

${ }^{58}$ Camden, 10 N.J. at 65, 89 A.2d at 443.

${ }^{59} \mathrm{Id}$. at 67,89 A.2d at 444 .

6o The "people's panel" characterization of the grand jury appears in the title of Younger's study of the history of the grand jury in the United States. See R. YounGER, supra note 33; see also In re April 1956 Term Grand Jury, 239 F.2d 263, 269 (7th Cir. 1956) (" $[W]$ hen exercising its traditional functions [the grand jury] possesses an independence which is unique. Its authority is derived from none of the three basic divisions of our government, but rather directly from the people themselves."); In re Report and Recommendation of June 5, 1972 Grand Jury Concerning Transmission of Evidence to the House of Representatives, 370 F. Supp. 1219, 1222 (D.D.C.) (emphasizing that the grand jury may act independently of any branch of government and pursue investigations without the consent or participation of the prosecutor), aff $d s u b$ nom. Haldeman v. Sirica, 501 F.2d 714 (D.C. Cir. 1974); In re Subpoena to Nixon, 360 F. Supp. 1, 9-10 (D.D.C.) ("The grand jury derives its authority directly from the people, and when that group, independent in its sphere, acts according to its mandate, the court cannot justifiably withhold its assistance . . . " (citations omitted)), modified, Nixon v. Sirica, 487 F.2d 700 (D.C. Cir. 1973).

${ }_{61}$ See Levine v. United States, 362 U.S. 610, 617 (1960) (stating that "[t]he grand jury is an arm of the court"); United States v. Kleen Laundry \& Cleaners, $381 \mathrm{~F}$. Supp. 519, 521-22 (E.D.N.Y. 1974) (discussing the prosecutor's dominance of the grand jury proceedings); Campbell, Eliminate the Grand Jury, 64 J. CRIM. L. \& CRIMINOLOGY 174, 174 (1973) (discussing a concern for the continued viability of the grand jury because of its subservience to the court and prosecutor); Lewis, The Grand 
the grand jury operates in a manner somewhere between these two views. Although exercising a degree of independence from executive domination and judicial control, the grand jury is ultimately dependent on government if it is to perform its functions. ${ }^{62}$ Even if the grand jury is an integral part of government, the reporting function can be viewed as a device that forces government to police itself. Public confidence in the accountability of government is then furthered by requiring government to identify its own misconduct.

In one respect, the public interest served by grand jury reports furthers values similar to those protected by applying the New York Times $^{\boldsymbol{\theta 3}}$ rule to defamation actions brought by public officials. If there is a strong public interest in protecting vigorous debate about the conduct of public officials, ${ }^{64}$ there is an equally compelling public interest in learning of official misconduct uncovered by a grand jury. ${ }^{65}$ On the other hand, the catalyst for the public debate furthered by the New York Times rule, the press, is a nongovernmental source that can claim first amendment protection for its speech. The weight to be accorded the first amendment interest furthered by a report, however, is less substantial than that furthered by the New York Times rule, since the grand jury is at least partially dependent on government to fulfill its functions ${ }^{86}$ and the extent of first amendment protection accorded governmental speech is problematic. ${ }^{\text {B7 }}$

Jury: A Critical Evaluation, 13 Akron L. REv. 33, 57 (1979) (stating that the grand jury is an "arm of the executive").

62 See United States v. Calandra, 414 U.S. 338, 346 n.4 (1974) (noting that the grand jury must rely on the court to compel production of books, documents, papers, and the testimony of witnesses); Brown v. United States, 359 U.S. 41, 49 (1959) (noting that the grand jury is "powerless itself to compel the testimony of witnesses"), overruled on other grounds, Harris v. United States, 382 U.S. 162 (1965).

${ }^{63}$ In New York Times Co. v. Sullivan, 376 U.S. 254 (1964), the Supreme Court held that the first amendment "prohibits a public official from recovering damages for a defamatory falsehood relating to his official conduct unless he proves that the statement was made with 'actual malice' - that is, with knowledge that it was false or with reckless disregard of whether it was false or not." Id. at 279-80.

64 See Garrison v. Louisiana, 379 U.S. 64, 77 (1964).

${ }^{65}$ See McClatchy Newspapers v. Superior Court, 209 Cal Rptr. 598, 604 (Cal. App. 1985) ("[T] of their state and local government including the activities of public officials in the performance of their official duties."); see also Emerson, Legal Foundations of the Right to Know, 1976 WASH. U.L.Q. 1, 2 (arguing for a first amendment right of access to information). But see Press-Enterprise Co. v. Superior Court, 106 S. Ct. 2735, 27392741 (1986) (first amendment right of access to information only when "place and process [of criminal proceedings] has historically been open to the press and general public" and when "public access plays a significant positive role in the functioning of the particular process in question").

${ }_{66}$ See supra note 62 and accompanying text.

67 Arguably, the purpose of the first amendment is to function only as a limitation on governmental power, not as a source of governmental rights. See M. YUDOF, WHEN 
Moreover, to further the first amendment interest of encouraging debate on public issues, the New York Times rule accepts the consequence that some unjustified attacks on reputation will go uncompensated under state libel standards. ${ }^{68}$ The harm to an official's reputation, however, is likely to be substantially greater when a defamatory falsehood appears in an official grand jury document released by a court than when the falsehood is expressed in ordinary public debate. ${ }^{69}$ The public interest in learning of official misconduct may not outweigh the interest of the official in protecting her reputation from possibly unfounded allegations if the accuser is publicly perceived as government and the official is denied an opportunity to respond to the grand jury's charges.

\section{The Lack of Forum Objection}

While Camden highlights the public interest furthered by reports that identify official misconduct, Justice Vanderbilt gave little consideration to the competing interests of the official criticized in the report. Justice Vanderbilt acknowledged that the primary objection to a report is that it fails to provide a forum for response, ${ }^{70}$ but he did not consider that concern sufficient to abolish the reporting function. Noting that other grand jury actions could also be criticized for failing to provide a forum for response, ${ }^{71}$ Justice Vanderbilt discounted the need for a fo-

Government Speaks: Politics, Law and Government Expression in America $44 \mathrm{n} .28$ (1983) (authority for proposition that several amendments in the Bill of Rights have not been extended to governmental bodies); Kamenshine, The First Amendment's Implied Political Establishment Clause, 67 CaLIF. L. Rev. 1104, 1153 (1979) (arguing that the first amendment contains an implied prohibition against governmental advocacy of political viewpoints); Van Alystyne, The First Amendment and the Suppression of Warmongering Propaganda in the United States: Comments and Footnotes, 31 Law \& Contemp. PRoBs. 530, 531-37 (1966) (arguing that the first amendment limits government propaganda). But see Schauer, Is Government Speech a Problem?, 35 StAN. L. REv. 373, 385 (1983) (arguing that limiting government speech is inconsistent with the marketplace of ideas); Note, The Constitutionality of Municipal Advocacy in Statewide Referendum Campaigns, 93 HARv. L. REv. 535, 541 (1980) (suggesting some basis for arguing that the first amendment protects municipal speech).

${ }^{68}$ See Gertz v. Robert Welch, Inc., 418 U.S. 323, 342-43 (1974).

69 See In re Grand Jury, 271 N.W.2d 817, 819 (Minn. 1978) ("The judicial imprimatur under which a grand jury operates gives to its pronouncements a ring of proven truth which they may not deserve."); Simington v. Shimp, 60 Ohio App. 2d $402,407-08,398$ N.E.2d 812, 816 (1978) ("any attempt by a named individual to rebut the contents of the report would not have, in the public's mind, the same 'official weight' as the report's original accusation").

${ }_{70}$ Camden, 10 N.J. at 66, 89 A.2d at 444.

${ }^{71}$ Id. at $67-68,89$ A.2d at 444 . As one example, Justice Vanderbilt noted that many indictments are never brought to trial. See, e.g., Judge Drops Election Case Against Fiedler and Aide, N.Y. Times, Feb. 27, 1986, at A18, col. 1 (court dismissed indictment); California Prosecutor Won't Pursue Case Against Rep. Fiedler, N.Y. 
rum to refute a report's charges of misconduct. The care with which grand jurors are selected and the ability of the court to refuse to file a report that appears false minimize the possibility that the grand jury's accusations will be unfounded. ${ }^{72}$ Since the report's charges are likely accurate, Justice Vanderbilt was not very troubled by the lack of forum objection.

Justice Vanderbilt's response to the lack of forum objection is less than satisfying. The public official's lack of a forum to respond to a critical report jeopardizes the basic fairness of the reporting function. ${ }^{73}$ Despite the best judicial efforts to ensure the accuracy of a report before release, the grand jury may publish a false report and the official would be denied a judicial forum in which to refute the allegations contained in the report.

Moreover, the issuance of a grand jury report will not provide an adequate alternative, nonjudicial forum for response in every case, as Justice Vanderbilt had intimated. On the one hand, public officials are likely to have easy access to the media and can use that access to respond to a report. ${ }^{74}$ Moreover, by voluntarily attaining office, public

Times, Feb. 20, 1986, at A14, col. 1 (prosecutor refused to oppose a motion seeking dismissal of a grand jury indictment).

${ }^{72}$ Camden, 10 N.J. at 67, 89 A.2d at 444.

73 Reports that reveal violations of the public trust can be challenged as violating procedural due process for failing to provide a mechanism for officials to protect their reputations from unfounded governmental accusations. The only state court case that considers the constitutionality of the reporting function under a due process analysis is In re Second Report of the November, 1968, Grand Jury, 26 N.Y.2d 200, 257 N.E.2d 859 , 309 N.Y.S.2d 297 (1970), in which the court held that New York's statute that authorizes and regulates the reporting function satisfied the due process clause of the state constitution. The court noted that the statute allows a public official to file an answer to a report before publication and interpreted the statute to permit the official to inspect the grand jury minutes in preparing that answer. Id. at 204-05, 257 N.E.2d at 861,309 N.Y.S.2d at 299-301. The New York reporting statute is discussed in greater detail infra at text accompanying notes 95-110.

A comprehensive analysis of the due process issues raised by the reporting function appears in a recently published treatise on the grand jury. See $1 \mathrm{~S}$. BEALE \& W. BRYSON, supra note $7, \S 3.04$. After reviewing the leading Supreme Court procedural due process cases, the authors conclude that a reporting procedure providing a public official with the opportunity to appear before the grand jury and to attach a response to a critical report complies with due process requirements. Although the authors acknowledge that it presents a "slightly more difficult question," $i d$., they conclude that a reporting function not including these features also withstands due process analysis if the official can challenge a report before publication. The authors' due process analysis, however, is based on the assumption that a report reveals noncriminal misconduct. See $i d$. Potential due process challenges to reports that reveal criminal misconduct are suggested infra at note 124 .

74 See Curtis Publishing Co. v. Butts, 388 U.S. 130, 164 (Warren, C.J., concurring) (1967) (public officials have "ready access . . . to mass media . . . to counter criticism of their views and activities"); see also Gertz v. Robert Welch, Inc., 418 U.S. 323,344 (1973) (public officials have "access to the channels of effective communica- 
officials assume an increased risk of scrutiny ${ }^{75}$ and subject themselves to a standard of conduct more demanding than that required by the criminal law. ${ }^{76}$

On the other hand, a public official's career depends on a positive reputation, which could be permanently damaged by a critical report. Although an official can respond to a report through the media, vindication in the public forum can never be as complete as vindication resulting from a judicial or other governmental determination that the official has not violated the public trust. ${ }^{77}$ Nine years after Camden, the New York Court of Appeals, in Wood $v$. Hughes, ${ }^{78}$ relied on the lack of forum objection to hold that New York grand juries no longer retained the authority to report on official misconduct.

\section{B. Hughes: Challenging the Public Interest and} Highlighting the Competing Interests of the Public Official

The disputed report in Hughes criticized practices of a county highway department as "contrary to the general interests of the public."'79 Although the grand jury did not identify the responsible officials, the court of appeals noted that the report left "little doubt as to their identity." ${ }^{\prime 80}$ The justice presiding over the grand jury refused to release the report except for a single paragraph which did not concern the highway department. ${ }^{81}$ The grand jury foreman unsuccessfully petitioned the appellate division to order the report's release and the New York Court of Appeals accepted review. ${ }^{\mathbf{2 2}}$

In Camden, Chiế Justice Vanderbilt gave substantial weight to New Jersey's long history of grand jury reports in holding that the

tion" and are therefore in a better position than a private person in countering harm to reputation from a defamatory falsehood made in public debate).

${ }^{75}$ Gertz, 418 U.S. at 344. See also RAYNer, Life Of Jefrerson 356 (Boston ed. 1832 ), in II J. Foley, The Jeffersonian CyClopedia $\$ 8596$, at 887 (1900) ("When a man assumes a public trust, he should consider himself as public property.").

${ }_{73}$ See supra note 1 and accompanying text.

77 See Simington v. Shimp, 60 Ohio App. 2d 402, 407-08, 398 N.E.2d 812, 816 (1978); Golladay, Sidestepping Due Process: Federal Grand Juries and the Unindicted Co-Conspirator, 65 JudiCature 363, 368 (1982) (describing the concept of defending oneself in the media as "a rather novel means of legal defense!").

${ }^{78} 9$ N.Y.2d 144, 154-56, 173 N.E.2d 21, 26-27, 212 N.Y.S.2d 33, 40-41 (1961), superseded by statute as stated in In re Report of the August-September, 1983 Grand Jury III, Term IX, Suffolk County, New York, 103 A.D.2d 176, 479 N.Y.S.2d 226 (1984).

79 Id. at 148,173 N.E.2d at 22,212 N.Y.S.2d at 34.

80 Id.

81 Id. That paragraph concerned windows in the county jail.

${ }^{82}$ Id. at 148,173 N.E.2d at 22-23, 212 N.Y.S.2d at 35. 
modern grand jury retained its common law reporting function. ${ }^{83}$ In contrast, Judge Fuld, writing in Hughes for a four-to-three majority of the court of appeals, dismissed the past reporting practices of New York grand juries as irrelevant ${ }^{84}$ and held that grand juries could no longer issue reports criticizing noncriminal misconduct by public officials. ${ }^{85}$ Judge Fuld found that the grand jury's common law authority had been supplanted by comprehensive legislative regulation and that the reporting function was not authorized either by state statute or the state constitution. ${ }^{86}$ Judge Fuld acknowledged that the legislature could restore the reporting function by a clear grant of authority, ${ }^{87}$ but his characterization of reports that identify official misconduct made it clear he was not recommending that action:

In the public mind, accusation by report is indistinguishable from accusation by indictment and subjects those against whom it is directed to the same public condemnation and opprobrium as if they had been indicted. An indictment charges a violation of a known and certain public law and is but the first step in a long process in which the accused may seek vindication through exercise of the right to a public trial, to a jury, to counsel, to confrontation of witnesses against him and, if convicted, to an appeal. A report, on the contrary, based as it is upon the grand jury's own criteria of public or private morals, charges the violation of subjective and unexpressed standards of morality and is the first and last step of the judicial process. It is at once an accusation and a final condemnation, and, emanating from a judicial

${ }^{83}$ See supra text accompanying note 54.

84 Hughes, 9 N.Y.2d at 154-55, 173 N.E.2d at 26, 212 N.Y.S.2d at 40 . The activism of New Jersey grand juries in exercising a public reporting function was matched by grand juries in New York. By 1961, approximately 500 reports had been filed in Manhattan alone. See id. at 156-57, 173 N.E.2d at 27-28, 212 N.Y.S.2d at 42 (Desmond, C.J., dissenting). Like the New Jersey reports, the New York reports concerned a wide variety of community concerns and occasionally revealed official misconduct. See Kuh, supra note 6, at 1104 \& n.5 (citing seven reports issued by four different New York City grand juries in 1954 within a nine-week period).

Grand jury reports were frequently challenged in New York before Hughes. In In re Jones, 101 A.D. 55, 92 N.Y.S. 275, appeal dismissed, 181 N.Y. 389, 74 N.E. 226 (1905), the only appellate decision before Hughes, the appellate division upheld a report that censured a county board of supervisors and two of its clerks. The lower courts in New York, however, were divided on whether grand juries could issue reports that identify official misconduct, with most adopting the view of the dissent in Jones and holding that the grand jury lacked that authority. See Hughes, 9 N.Y.2d at 148 \& n.2, 173 N.E.2d at 22 \& n.2, 212 N.Y.S.2d at 35 \& n.2.

${ }_{85}$ Hughes, 9 N.Y.2d at $155-56,173$ N.E.2d at 27,212 N.Y.S.2d at $40-41$.

${ }^{86}$ Id. at 149-51, 173 N.E.2d at 23-26, 212 N.Y.S.2d at 36-39.

87 See infra text accompanying note 91 . 
body occupying a position of respect and importance in the community, its potential for harm is incalculable. ${ }^{88}$

Although Judge Fuld was highly critical of the reporting function, he readily embraced the principles that public officials should be held to a high standard of behavior and that "criticism of the conduct of public office is part of the very lifeblood of our democracy." grand jury report, he argued, is ill-suited to further those objectives. The secrecy that surrounds grand jury deliberations and the immunity that protects grand jurors creates a "grave danger that grand jury reports may as readily be used as instruments of unfair partisan politics as of public enlightenment."90 Accordingly, Judge Fuld concluded that the issue raised by a report

is not the integrity of a public official or his performance in office, but rather the process or procedure to be employed in charging and judging him. To be deplored, and avoided in the absence of a clear grant of legislative authority, is not public criticism of officials, but criticism contained in a court report which, while it carries, at least, the aura of a judicial pronouncement, denies to the persons involved any of those safeguards designed to protect against the violation of cherished individual rights. ${ }^{91}$

If Camden presents the classic argument in support of the grand jury's reporting authority, Hughes undoubtedly advances the definitive counterarguments. Judge Fuld's objections to reports that identify official misconduct reflect two primary concerns. The first focuses on the possible abuse of the reporting function and the second on the public's inability to distinguish between accusation by report and accusation by indictment.

\section{Abuse of the Reporting Function: New York's Response}

Judge Fuld, unlike Justice Vanderbilt, feared that the nature of the grand jury process, coupled with a vague standard for official misconduct, would create a "grave danger" that the reporting authority could be used for purposes other than public enlightenment. ${ }^{92}$ The danger of abuse arises because the grand jury's findings need not be estab-

\footnotetext{
${ }^{88}$ Hughes, 9 N.Y.2d at 154, 173 N.E.2d at 26, 212 N.Y.S.2d at 39-40.

89 Id. at 156,173 N.E.2d at 27,212 N.Y.S.2d at 41.

${ }^{80}$ Id. at 155,173 N.E.2d at 27,212 N.Y.S.2d at 41.

${ }^{21}$ Id. at 156, 173 N.E.2d at 27, 212 N.Y.S.2d at 41.

22 See supra text accompanying notes 90-91.
} 
lished in an adversarial proceeding ${ }^{93}$ and the official may never completely vindicate himself by publicly refuting false charges.

If the reporting process creates a substantial danger of abuse, the public interest furthered by reports is diminished. Rather than being used to support democracy by exposing governmental misconduct, reports could be used for political ends to harass public officials with false charges. ${ }^{94}$ By implicitly challenging Justice Vanderbilt's characterization of the public interest furthered by the reporting function, Judge Fuld reduced the significance of that interest and gave greater weight to the interests of the official criticized by the grand jury.

A grand jury or prosecutor may be tempted to abuse the reporting authority as Judge Fuld feared. If, however, one can minimize the possibility of abuse and create forums to allow a response by the official, the potential for abuse need not defeat the legitimate use of the grand jury report to further the public interest. For example, two years after Hughes, the New York legislature authorized grand juries to report on "misconduct, non-feasance or neglect in public office by a public servant as the basis for a recommendation of removal or disciplinary action." ${ }^{\text {"9s }}$ At the same time, it comprehensively regulated the reporting

${ }^{83}$ Many of the procedural protections of trial are not present in grand jury proceedings. See, e.g., United States v. Calandra, 414 U.S. 338, 345-52 (1974) (evidence inadmissible at trial is permitted in grand jury); Costello v. United States, 350 U.S. 359,363 (1956) (hearsay evidence is admissible in grand jury); Hammond v. Brown, 323 F. Supp. 326, 338 (N.D. Ohio) (witness before grand jury not entitled to have attorney present), affd, 450 F.2d 480 (6th Cir. 1971).

94 See H.R. REP. No. 1549, 91st Cong., 2d Sess. 183, reprinted in 1970 U.S. Code Cong. \& Admin. News 4007, 4078 (statement of Rep. Conyers) (concern about smear campaigns voiced in House Debate in opposition to federal reporting statute).

${ }^{25}$ N.Y. GRIM. Proc. Law \& 190.85(1)(a) (McKinney 1982). The New York statute served as a model for federal legislation that authorized special grand juries investigating organized crime conditions to issue public reports "concerning noncriminal misconduct, malfeasance, or misfeasance in office involving organized criminal activity by an appointed public officer or employee as the basis for a recommendation of removal or disciplinary action." 18 U.S.C. $\$ 3333(a)(1)$ (1982) (emphasis added). In arguing against passage of the Organized Crime Control Act, which included the federal reporting statute, Representatives Conyers, Mikva, and Ryan compared grand jury reports to "sanctified calumny" and invited supporters of the bill to "first ponder why the Senate version of this bill was amended by the House committee to exclude elected officials from the reach of these mini-star chambers." H.R. REP. No. 1549, 91 st Cong., 2d Sess. 182, reprinted in 1970 U.S. Code Cong. \& AdmIN. News 4007, 4078.

When the House considered passage of the Organized Crime Control Act, Representative McCulloch explained why the House Judiciary Committee amended the Senate version of the bill to limit the reporting authority to reports that concern appointed public officers and employees:

The limitation has two purposes. The first is to keep the special grand jury from "playing politics." Some members of the committee feared that a special grand jury might be tempted to abuse its power by trying to influence the outcome of an election.

The second purpose of the limitation is to protect further this grant of 
process to prevent the abuses that concerned Judge Fuld.

The key provision of New York's statutory scheme mandates judicial review of a report before publication. For the report to be accepted for filing as a public record, the court that impaneled the grand jury must determine that the report's findings are supported by a preponderance of legally admissible evidence ${ }^{96}$ and that the official was afforded the opportunity to testify before the grand jury. ${ }^{97}$ If these condi-

\begin{abstract}
power to the special grand jury from attack on grounds that it violates the due process clause. Some have criticized this provision in the Senate bill as granting the special grand jury what is in effect the power to indict without according the identified individual the opportunity for vindication. The phrase - as the basis for a recommendation of removal or disciplinary action-did not make sense when applied to instances of elected officials such as mayors or governors. To whom would the recommendation be made? The people? Who had the authority to remove or discipline such an official? If no such power to remove or discipline existed, was the special grand jury yet authorized to issue the report?

The answers to such questions become evident when the reporting power is limited to appointed officers and employees. Then the report may be viewed as a recommendation to the appointing agency to remove or to discipline. The identified individual thus has a further recourse. He may present his case anew to the appointing agency. He will have an opportunity to vindicate his position. The analogy to an indictment without a trial is no longer valid.
\end{abstract}

116 Cong. Rec. 35,198 (1970) (remarks of Rep. McCulloch).

Representative Eckhart was not persuaded by this explanation and offered an amendment to restore the reporting authority over elected public officials, as it had appeared in the Senate bill. See id. at 35,329-32 (remarks of Rep. Eckhart). Representative Eckhart argued that "all public officers, including elected officials, should be included if anyone is to be included," and that the "elected mayor, sheriff, or Congressman, has a stump from which to speak" to the charges but that the nonelected public employee did not. Id. at 35,330. Echoing these concerns, Representative Koch predicted that the public would view the House's limitation as "meaning the Members of Congress[] are willing to tell others what they shall do ... but that we the Congress, in our own protection and to protect every other public official, are not willing to be governed by the same restrictions." Id. at 35,331 (remarks of Rep. Koch). Koch also noted that the lack of forum objection to grand jury reports was even less persuasive when applied to an elected official since, the official "generally has a forum from which to defend himself, whereas the appointed official often does not." Id.

Representative Eckhart's amendment was rejected by the House. Id. at 35,332. The Senate ultimately accepted the House changes to the bill, $i d$. at 35,296 , but Senator McClellan, one of the act's original sponsors, referred to the House exemption of elected officials as "the most weakening amendment [to the bill] passed by the House." Id. at 36,293 (statement of Sen. McClellan).

${ }^{86}$ N.Y. CRIM. Proc. LAW § 190.85(2)(a) (McKinney 1982). Compare 18 U.S.C. $\S 3333(b)(1)(1982)$ (requiring a report to be supported by a preponderance of the evidence without requiring that the evidence be legally admissible) with N.J. R. CRIM. PRAC. 3:6-9(c) (before "a public official is censured [in a report] the proof must be conclusive that the existence of the condemned matter is inextricably related to noncriminal failure to discharge his public duty" (emphasis added)).

${ }_{97}$ N.Y. CRIM. Proc. LAw $\S 190.85(2)(\mathrm{b})$ (McKinney 1982); accord 18 U.S.C. $\S 3333(\mathrm{~b})(2)$ (1982) (before report is accepted for filing the official and witnesses in official's behalf must have been afforded an opportunity to testify). But see N.J. R. 
tions are met, the report must then be temporarily sealed and served on the official, who can file a defense to the grand jury's findings. ${ }^{98}$ In framing the defense, the official is allowed access to the grand jury minutes. ${ }^{99}$ If the court releases the report over the objection of the official, the official's defense must be included as an appendix to the report. ${ }^{100}$ The official has the right to appeal a decision to release the report and the report remains sealed while the appeal is pending. ${ }^{101}$

This approach to regulating the reporting function accomplishes several objectives and responds directly to the leading criticisms of grand jury reports that reveal official misconduct. First, prepublication review creates a judicial forum and an appeal procedure for the official to challenge a report before release and, along with the requirement that the official be afforded an opportunity to testify before the grand jury, likely removes any procedural due process objections to the reporting function. ${ }^{102}$ Second, the possibility that the grand jury will use a report to knowingly bring false or reckless charges is reduced since the report must be submitted to the court and served on the criticized official for review before publication. ${ }^{103}$ Third, the concern that the secrecy that surrounds the grand jury process will encourage abuse is addressed, since the official can review the grand jury proceedings that led

CRIm. Prac. 3:6-9(c) (no requirement that official have chance to testify).

${ }_{98}$ N.Y. CRIM. PROC. LAw $\S 190.85(3)$ (McKinney 1982); accord 18 U.S.C. $\S 3333(c)(1)-(2)$ (1982) (largely identical to New York provision); N.J. R. GRIM. PRAC. 3:6-9(c) (official has 10 days to file a motion to dispute the report).

${ }^{99}$ See In re Second Report of the November, 1968 Grand Jury, 26 N.Y.2d 200, 204-05, 257 N.E.2d 859, 860-61, 309 N.Y.S.2d 297, 299-300 (1970); see also N.J. R. CRIM. Prac. 3:6-9(c) (official can fully examine the grand jury minutes under court supervision). When the grand jury issues a report that reveals a violation of the public trust, traditional justifications for grand jury secrecy are no longer compelling. See In $r e$ the Presentment Made to the Superior Court by the Camden County Grand Jury, 1959 Term, First Stated Session, on or About June 7, 1960, 34 N.J. 378, 401, 169 A.2d 465, 477 (1961) (veil of secrecy of proceedings not sacrosanct).

100 N.Y. CRIM. Proc. LAW § 190.85(3) (McKinney 1982). Portions of the defense that the court determines "to be scandalously or prejudicially and unnecessarily inserted therein" can be excluded. Id.; see also 18 U.S.C. § 3333(c)(2) (1982) (court shall include official's defense as an appendix to the report). The New Jersey court rule that regulates the reporting function does not authorize the court to include an official's defense as an appendix to the report. N.J. R. CRIM. PRAC. 3:6-9(c).

101 N.Y. Crim. Proc. Law § 190.90(1), (4) (McKinney 1982 \& Supp. 1987).

See also N.J. R. CRIM. Prac. 3:6-9(d) (judge must delay publication pending hearing). Although the right to appeal release decisions under the federal reporting statute is not specifically provided for, appeals were clearly contemplated. See 18 U.S.C. $\S 3333$ (c)(1)(ii) (1982) (court shall delay releasing report during pendency of appeal).

102 See supra note 73.

103 N.Y. CRIM. Proc. Law § 190.85(1)-(3) (McKinney 1982). In California, as an added deterrent to abuse, the immunity generally protecting grand jurors can be removed if a report that contains false charges is made knowingly or recklessly without bringing indictment. See Calif. Penal Code $\S 930$ (West 1985) (removing the grand jurors' immunity whenever a report comments on a person who has not been indicted). 
to the report. ${ }^{104}$ Fourth, the likelihood that the grand jury's charges are accurate is increased since release depends on a judicial determination that the report is supported by a preponderance of the evidence. ${ }^{105}$ Fifth, by requiring release of the official's defense with the report, ${ }^{106}$ New York ensures the official's access to the public forum simultaneously with the report's publication and mitigates the perception of a report as a "foul blow" that allows no opportunity for a response. Finally, a report must recommend the removal or discipline of an official criticized for misconduct. ${ }^{107}$ Publication of the report may therefore prompt the initiation of an adversarial proceeding in which the public official can respond to the grand jury's charges. ${ }^{108}$

Regulating the reporting function to this degree provides the public official with greater protection from possible abuse of the grand jury process than if the official had been indicted. ${ }^{109}$ The court can block an unsubstantiated report from being published, while the official cannot challenge an indictment until it is returned. ${ }^{110}$ Prepublication judicial review minimizes the possibility that the reporting function will be abused, and, if it is, judicial review prevents the report from being released.

New York's regulatory scheme also provides a public official with opportunities to respond to a grand jury's charges of misconduct. The most effective forum is the official's ability to object to a report during prepublication judicial review and to prevent release of unjustified findings. If the report is published, the official's defense, attached as an

104 See supra note 99 and accompanying text.

${ }^{100}$ See supra note 96 and accompanying text.

${ }^{108}$ See supra note 100 and accompanying text.

107 See supra note 95 and accompanying text.

108 The federal reporting statute also requires that a report serve as the basis for the grand jury's recommendation that disciplinary or removal proceedings be initiated but only authorizes reports concerning misconduct by appointed public officers or employees. See 18 U.S.C. \& 3333(a)(1) (1982); supra note 95.

109 See Weinstein \& Shaw, Grand Jury Reports-A Safeguard of Democracy, 1962 WASH. U.L.Q. 191, 204 (grand jury reports offer a fairer and more effective investigatory forum than an indictment because of the "judicial controls" inherent in the process). But see H.R. REP. No. 1549, 91st Cong., 2d Sess. 183, reprinted in 1970 U.S. CoDE Cong. \& ADMIN. News 4007, 4078-79 (statement of Rep. Conyers) (arguing that federal reporting statute, which provides procedural safeguards similar to New York statute, offers "illusory" protections for public officials).

Whether the New York safeguards should apply to the reporting function was challenged in In re Second Report of the November, 1968 Grand Jury, 26 N.Y.2d 200, 218, 257 N.E.2d 859, 869, 309 N.Y.S.2d 297, 311 (Breitel, J., dissenting) ("The most shocking discrimination, however, is that criminal defendants, with so much more at stake, have no protection or 'due process' similar to that being accorded to public officers and employees who are being criticized with less than crime.").

110 Most courts hold that indictments are not even subject to the challenge that the evidence before the grand jury was insufficient to indict. See infra note 236. 
appendix, ensures access to the public forum. Finally, if a disciplinary or removal proceeding is triggered by the report, the official can respond effectively to the grand jury's accusation of misconduct in an adversarial proceeding.

\section{Distinguishing Between Reports and Indictments}

The preceding discussion suggests that the reporting function can be regulated to minimize the possibility of abuse. Given the strong public interest in revealing violations of the public trust, combined with the ability to protect an official's reputation from unjustified grand jury accusations, one might conclude that the grand jury should have the authority to report on official misconduct. The discussion to this point, however, does not respond to Judge Fuld's second objection to the reporting function: the public's inability to distinguish between accusations by report and those by indictment. ${ }^{111}$ A discussion of that objection raises the difficult issue of which violations of the public trust can be revealed by a report and which violations should be revealed only by an indictment.

\section{a. The Source of the Problem and the New Jersey Solution}

Public confusion about the significance of a report's accusation of misconduct may be traced to a grand jury's uncertainty as to whether the misconduct is indictable, or to a prosecutor's uncertainty as to whether the misconduct is sufficient to obtain a conviction. Such uncertainties can arise from two possible sources: quantitative and qualitative evidentiary problems. ${ }^{112}$ To illustrate each, recall the hypothetical posed in the introduction to the Article concerning the public official who takes a discretionary action to benefit a campaign contributor. ${ }^{113}$ Expanding upon the hypothetical, assume that the contributor made a substantial contribution to the official's election campaign the day before the official acted favorably to the contributor and that the contribution was reported to the state election commission as required by law.

Quantitative evidentiary problems concern whether there is sufficient evidence to establish the elements of a crime. For example, in the bribe receiving hypothetical, the prosecution may be unable to establish that the official received a contribution as a quid pro quo for an action

\footnotetext{
111 See supra text accompanying note 88.

112 I am grateful to my colleague Arthur Leavens for suggesting this distinction.

11 See supra text accompanying note 4.
} 
favoring the contributor. In turn, this lack of quantitatively sufficient evidence can cause the prosecution to fail at either of two points: at the indictment stage, or at the conviction stage. Each stage involves a different standard of proof. An indictment requires that the evidence before the grand jury establish probable cause or a prima facie case that the defendant committed a crime, ${ }^{114}$ while a conviction requires that the defendant's guilt be established beyond a reasonable doubt. ${ }^{115}$

Unlike quantitative evidentiary problems, qualitative evidentiary problems concern whether the evidence, regardless of its strength, can establish the defendant's criminal liability as a matter of law. For example, assume that the issue of whether a reported campaign contribution is a benefit under the bribe receiving statute has not been addressed in the jurisdiction. ${ }^{116}$ If the official is indicted on the theory that the campaign contribution establishes the receipt of a benefit, the indictment may be challenged by a motion to dismiss. ${ }^{117} \mathrm{~A}$ reported campaign contribution may not be, as a matter of law, the type of evidence that can ever establish that a benefit was received under the statute.

If the grand jury issues a report as an alternative to a prosecution presenting evidentiary problems, whether quantitative or qualitative, ${ }^{118}$

114 The United States Supreme Court has frequently referred to a probable cause standard as the quantum of proof required to support an indictment. See Vasquez v. Hillery, 106 S. Ct. 617, 623 (1986); United States v. Calandra, 414 U.S. 338, 343 (1974); Branzburg v. Hayes, 408 U.S. 665, 686-87 (1972). Federal courts differ, however, in their definitions of that standard for the grand jury. See Arenella, Reforming the Federal Grand Jury and the State Preliminary Hearing to Prevent Conviction Without Adjudication, 78 MrCH. L. Rev. 463, 485-87 (1980) (some courts and the Department of Justice equate the probable cause standard to indict with the probable cause standard to arrest, whereas other courts follow a more rigorous "probability-ofconviction" probable cause standard).

Standards that govern prosecutorial discretion refer to a probable cause or prima facie evidence standard as the minimum level of proof required to initiate criminal charges. See, e.g., Model Rules of Professional Conduct Rule 3.8(a) (1983) (prosecutor shall "refrain from prosecuting a charge that the prosecutor knows is not supported by probable cause"); Standards Relating to the Prosecution FuncTION § 3.9(e) \& Commentary (Approved Draft 1971) (standard requires the prosecutor to only bring charges that "he can reasonably support with evidence at trial," and commentary equates standard with prima facie evidence test); U.S. DEPARTMENT of Justice, Principles of Federal. Prosecution B.1.(a) \& Comment (1980) (prosecutor may not institute charges without "probable cause to believe that a person has committed a federal offense").

${ }_{110}$ See, e.g., In re Winship, 397 U.S. 358, 361 (1970).

116 Several states preclude an official's conviction for receiving such a contribution. See, e.g., AlaSka StaT. § 11.56 .130 (1985); OR. Rev. STAT. \$ 162.005(1) (1985).

117 See FED. R. CRIM. P. 12(b). This may occur because the charge fails to allege a necessary element of the crime. Cf. United States v. Clark, 646 F.2d 1259, 1262 (8th Cir. 1981) (court characterized defendant's appeal of RICO conviction as an attack upon the indictment for failure to charge an offense).

${ }^{118}$ This distinction between quantitative and qualitative evidentiary problems is 
and the report contains ambiguous language relating to evidentiary sufficiency, the public may be unable to distinguish between accusation by report and accusation by indictment. Rather than risk an unsuccessful prosecution, the grand jury may prepare a report that reveals the official's violation of the public trust. Since the official's misconduct may also have been indictable, and perhaps even sufficient to establish the elements of a crime beyond a reasonable doubt, readers might view the report as a criminal accusation.

New Jersey's approach to regulating the reporting function provides one response to alleviating the concern that accusation by indictment and by report are indistinguishable. New Jersey reports may only be issued to censure a public official for "non-criminal" misconduct. ${ }^{119}$ As part of a report's prepublication judicial review, the court must determine whether "it appears that a crime has been committed for which an indictment may be had." 120 The court must strike any portion. that appears to accuse a public official of a crime, ${ }^{121}$ and a report may not be published if the evidence before the grand jury was indictable. ${ }^{\mathbf{1 2 2}}$

This approach responds to Judge Fuld's concern. Public confusion about the significance of a report is likely to be greatest when the grand

concededly arbitrary. Insufficient quantitative evidence to establish an element of a crime, for example, may be viewed as lacking either the quantity or the quality required to support an indictment or a conviction. Regardless of the label of the evidentiary problem, however, the discussion illustrates general categories of evidentiary issues in a grand jury investigation of possible criminal misconduct.

${ }_{119}$ N.J. R. Grim. Prac. 3:6-9(c). The federal reporting statute also limits the reporting authority to revelations of noncriminal misconduct. See supra note 95 . When the House debated the federal statute, Representative Eckhart proposed an amendment authorizing reports "concerning misconduct, malfeasance, or misfeasance in office, whether or not itself criminal." 116 CoNG. REC. 35,329 (1970) (statement of Rep. Eckhart) (emphasis added). Eckhart argued that this amendment was required to prevent "a very artificial procedure in which a person could say "because I engaged in a crime, you cannot make a report about me." Id. at 35,330. Representative Poff responded that since a grand jury had the power to indict or report, "it would be inappropriate in the extreme for a jury assembled to make a report charging criminal conduct and fail to indict." Id. at 35,331 (statement of Rep. Poff). Representative Eckhart's amendment was defeated by the House. Id. at 35,332 .

${ }^{120}$ N.J. R. CRIM. PraC. 3:6-9(c). In making that determination, the court is authorized to examine the grand jury minutes. $I d$.

121 See In $r e$ the Presentment Made to the Superior Court by the Camden County Grand Jury, 1959 Term, First Stated Session, on or About June 7, 1960, 34 N.J. 378, 393, 169 A.2d 465, 473 (1961); see also supra note 20.

122 In re Investigation into Hamilton Township Bd. of Educ., 205 N.J. Super. 248, 250, 500 A.2d 744, 745 (App. Div. 1985) ("Prior to [preparing a report] censuring a public official for abuse of his office, the Grand Jury must resolve that the evidence before it is insufficient or lacking for a criminal indictment against him for the same wrongdoing."); In re Presentment of Essex County Grand Jury, 110 N.J. Super. 24, 28, 264 A.2d 253, 254 (App. Div. 1970) (The grand jury may not replace a report for an indictment and the report "may censure a public official for some nonindictable conduct on his part." (emphasis omitted)); see also supra note 22. 
jury reveals conduct that may establish a crime or its report otherwise suggests a criminal violation of the public trust. If the release of such reports is blocked by prepublication judicial review, public confusion about the reporting function can be reduced. At the same time, prohibiting reports that reveal indictable misconduct coincides with Justice Vanderbilt's sweeping praise of the reporting function as a device that holds public officials accountable for "official acts and omissions that fall short of criminal misconduct and yet are not in the public interest." ${ }^{\text {123 }}$ If the misconduct is indictable, the public interest in reviewing the actions of public officials and holding them accountable for violations of the public trust would be served by an indictment. The subsequent prosecution would reveal the misconduct, and protect the official from an unjustified criminal accusation by providing the procedural safeguards of a criminal trial. ${ }^{124}$

\section{b. Problems with the New Jersey Solution}

Prohibiting the reporting function when a violation of the public trust is indictable, the New Jersey solution, does not always serve the interests of the public or the public official. To illustrate, assume in the hypothetical bribery investigation that although the quid pro quo element can probably be established beyond a reasonable doubt at trial, there is also a substantial possibility that the official will be acquitted. Fearful of the negative publicity that may result from an acquittal, the

${ }^{123}$ Camden, 10 N.J. at 66, 89 A.2d at 444; see supra text accompanying note 54.

124 The use of a report to accuse a public official of criminal misconduct may also be subject to constitutional challenge as a violation of due process and the fifth amendment right to indictment. Cf. United States v. Briggs, 514 F.2d 794, 802 (5th Cir. 1975) (naming of private persons as unindicted coconspirators exceeds the grand jury's authority and violates the procedural due process rights of those named); In re Jordan, 439 F. Supp. 199, 208 (S.D. W. Va. 1977) (naming of a private person as an unindicted coconspirator violates "his due process right to be permitted the protection of the federal indictment process as it is secured to him under the Fifth Amendment and the Federal Rules of Criminal Procedure."). But of. Note, Federal Grand Juries May Not Name Unindicted Coconspirators, 54 TEx. L. REv. 663, 672 (1976) ("When the grand jury, desiring to indict an individual, accedes to the prosecutor's request to name the individual an unindicted coconspirator, both the historical presentment power of the grand jury and the public's interest in the faithful execution of the laws by the Executive combine to mitigate the due process considerations."). For a discussion of the issues raised by a grand jury naming a person as an unindicted coconspirator, see generally Golladay, supra note 77.

The courts in Briggs and Jordan distinguished the grand jury's authority to issue reports accusing a public official of noncriminal misconduct from its action of accusing a person of criminal misconduct by naming the person as an unindicted coconspirator. See Briggs, 514 F.2d at 801, 805-06; Jordan, 439 F. Supp. at 204-05. Neither court challenged the constitutionality of the grand jury's authority to report on noncriminal misconduct by public officials. See supra note 73 . 
prosecutor may recommend against indictment. ${ }^{128}$ The prosecutor could not, however, advise the grand jury to issue a report that reveals the results of its investigation since the evidence before the grand jury is indictable. The grand jury would instead be required to choose between returning a no-true bill or an indictment, the same choices it faces in any criminal investigation.

If a no-true bill is returned, the public may never learn of the official's violation of the public trust that occurred when discretionary action was taken to benefit the contributor. On the other hand, if a prosecution is initiated, the central issue at trial will be whether the official's action was a quid pro quo for the contribution, not whether the official disregarded the public interest. An acquittal may create the public perception that the official has been exonerated of all wrongdoing, even though the only issue decided was whether the elements of the crime of receiving a bribe were established beyond a reasonable doubt. ${ }^{126}$ Therefore, the New Jersey rule is not always in the public's best interest.

Similarly, a prosecution, compared to a report, may not always benefit the official. Although it provides a forum for response, a prose-

125 In his article discussing the multitude of factors influencing prosecutorial discretion, Professor Kaplan noted how the fear of losing highly publicized prosecutions affected charging decisions when he was an Assistant United States Attorney:

There were also some very personal reasons for the assistant to exercise caution in authorizing prosecution. Although he was under relatively little supervision in his daily activities, he had to be careful to stay in the good graces of the United States Attorney, who, holding an essentially political position, was very sensitive to the criticism of the press, the judges, and the defense bar, all of whom were quick to note a rising number of acquittals and ascribe this to either incompetence in the staff or to overzealousness in the choice of targets for prosecution. The feeling that it was important to make certain that the office came under no undue criticism applied with additional force where the defendant was prominent in the community. Though such prosecutions, of course, were not always successful, it was generally felt that where the public eye would be on the prosecution, the criticism would be all the more severe if the case were lost. As a result, it was often stated that "if you go after a big one, you must be pretty sure you can get him."

Kaplan, The Prosecutorial Discretion-A Comment, 60 Nw. U.L. Rev. 174, 181 (1965); see also Frampton, Some Practical and Ethical Problems of Prosecuting Public Officials, $36 \mathrm{MD}$. L. REv. 5, 18 (1976) (noting that prosecutors in the Watergate investigation employed a higher standard of proof for recommending indictment than probable cause). But see Baron, A Response: Watergate Procedures for All?, $36 \mathrm{MD}$. L. REv. 35, 37-38 (1976) (a criticism of Frampton's view that a higher standard for indictability should be applied in public corruption cases because it creates "a double or even triple standard in the administration of justice. . . By formulating variable norms in order to do justice in different types of cases . . . we are evading our commitment to equality and neutral principles in the administration of justice.").

${ }^{128}$ See infra text accompanying notes 193-94. 
cution also creates the risk of a criminal conviction and sanction. If given a chance, many officials would no doubt prefer that the grand jury issue a report rather than an indictment. ${ }^{\mathbf{1 2 7}}$

Although New Jersey's rule forces the grand jury to initiate a prosecution to reveal noncriminal misconduct, it also partially responds to Judge Fuld's criticism of the reporting function as premised on the application of a vague concept of misconduct. By adopting a "bright line" nonindictability standard for the exercise of the reporting authority, New Jersey's approach specifies the type of misconduct that may be revealed by a report: noncriminal official misconduct.

Judge Fuld would no doubt respond that any standard of misconduct used to define the scope of the reporting authority is fatally vague, as it is ultimately based upon "the grand jury's own criteria of public or private morals, [that charge] the violation of subjective and unexpressed standards of morality."128 That criticism of the reporting function, however, is not particularly troubling.

Rather than being based on "subjective and unexpressed standards of morality," the circumstances that constitute official misconduct are described by the common law and statutory fiduciary standards imposed on public officials. ${ }^{129}$ Those standards are frequently applied in two situations: noncriminal proceedings where public officials are held accountable for violating the public trust through discipline and removal and criminal prosecutions where accountability is imposed through a criminal sanction.

As judicially interpreted and applied, the fiduciary standards im-

${ }^{127}$ One option for allowing the grand jury to issue a report when it uncovers indictable misconduct is to authorize a limited report that excludes the incriminating evidence. In the bribe receiving hypothetical, under this approach, the grand jury could reveal that the official took a discretionary action at the request of the contributor but not that a contribution was received the day before the action. This approach publicizes the violation of the public trust, yet removes the inference of criminality raised by the recent contribution.

A "sanitized" report, however, is unlikely to satisfy either the official or the supporters of the reporting authority. The official may object that the grand jury has implicitly suggested that she committed a crime by her actions because of the contributor's past support and that the release of the report will inevitably lead to discovery of the recent contribution. For example, the report's release may initiate a review of campaign contributions on file with the State Election Commission. Supporters of the reporting function will assert the public's right to know all the grand jury's evidence relevant to the violation of the public trust.

${ }^{128}$ Hughes, 9 N.Y.2d at 154, 173 N.E.2d at 26, 212 N.Y.S.2d at 40; see also Ex parte Burns, 261 Ala. 217, 221, 73 So. 2d 912, 915 (1954) (report allows grand jury "to set up its own standards of public or private morals"); Comment, supra note 6, at 719 (stating that a mixture of law, ethics, and individual notions of morality guide the grand jury in censuring persons for noncriminal conduct).

${ }^{129}$ See supra notes $1,4$. 
posed on public officials in noncriminal cases appear no less precise nor any more subjectively moral than some of the standards the grand jury uses to initiate criminal prosecutions. ${ }^{130}$ If the lack of a precise standard of prohibited behavior is sometimes unavoidable in the grand jury's criminal accusatory role, general standards that define improper conduct by public officials should likewise not prevent the grand jury from exercising its reporting function. Moreover, recent statutory efforts to comprehensively regulate the conduct of public officials have clarified the extent of the official's common law fiduciary duties by precisely describing prohibited behavior, ${ }^{131}$ and those specific standards can be used by the grand jury in its reporting function.

The standards under which the grand jury should exercise the re-

${ }^{130}$ For example, a finding that a public official knowingly failed to perform a duty "clearly inherent in the nature of his office" establishes the crime of official misconduct under New York's penal code. See N.Y. PENAL LAW § 195.00(2) (McKinney 1975).

Model Penal Code $\S 2.02(2)(c)$ (Proposed Official Draft 1962) defines the culpable mental state of "recklessly" as follows:

A person acts recklessly with respect to a material element of an offense when he consciously disregards a substantial and unjustifiable risk that the material element exists or will result from his conduct. The risk must be of such a nature and degree that, considering the nature and purpose of the actor's conduct and the circumstances known to him, its disregard involves a gross deviation from the standard of conduct that a lawabiding person would observe in the actor's situation.

This definition has been substantially adopted by most recent state criminal code revisions. See I Model Penal Code and Commentaries $\S 2.02$ commentary (Official Draft and Revised Comments 1985). In discussing the definition, the drafters of the Model Penal Code acknowledged the value judgment that it required of the jury:

Some principle must be articulated, however, to indicate what final judgment is demanded after everything is weighed. There is no way to state this value-judgment that does not beg the question in the last analysis; the point is that the jury must evaluate the conduct and determine whether it should be condemned.

Model Penal Code $\S 2.02$ commentary (Tent. Draft No. 4, 1955).

In addition, prior to McNally v. United States, 107 S. Ct. 2875 (1987), public officials had been prosecuted under the federal mail fraud statute, 18 U.S.C. $\$ 1341$ (1982), for depriving the public of its right to "honest and faithful services." United States v. Isaacs, 493 F.2d 1124, 1150 (7th Cir.), cert. denied, 417 U.S. 976 (1974). In McNally, however, the Court examined the legislative history of the mail fraud statute and concluded that the statute only applied to fraudulent schemes for obtaining property and did not protect the public's intangible right to good government. McNally, 107 S. Ct. at 2879. The Court, however, did not hold that the Congress lacked authority to protect intangible rights under the mail fraud statute, but rather, that if it intends to protect such rights, "it must speak more clearly than it has." Id. at 2881.

132 See, e.g., Conn. Gen. Stat. ANN. § 1-84(g) (West Supp. 1987) (prohibiting public official from soliciting or accepting anything of value, based on understanding that favorable official action would be forthcoming); FLA. STAT. ANN. $\S 112.313(3)$ (West 1982) (prohibiting public official from doing business with a company in which she or her family has a material interest). 
porting function when a violation of the public trust may also be criminal are, however, difficult to define. As the coverage of the criminal law continues to expand in regulating the conduct of public officials, many violations of the public trust will also implicate criminal offenses. ${ }^{\mathbf{1 3 2}}$ Limiting the reporting function to the ability to reveal noncriminal misconduct does little to define the scope of the grand jury's authority, except when a violation of the public trust is not regulated by the criminal law. ${ }^{133}$

Defining the reporting authority by reference to the indictability of the official's misconduct admittedly guides the grand jury, the prosecutor, and the court in determining when a report may be prepared and published. At the same time, it forces the grand jury to initiate a prosecution to reveal indictable misconduct even though there may be a substantial chance that a conviction cannot be obtained. In some instances, however, the grand jury and prosecutor may conclude that the public interest can be more effectively served by revealing official misconduct in a report rather than by initiating a prosecution. Can the public interest furthered by the reporting function ever outweigh the interests of a public official when a report reveals an indictable violation of the public trust? This issue is raised by the Watergate and Alaska Impeachment Reports.

\section{G. The Watergate Report: Balancing the Competing Interests}

As the grand jury investigation into the Watergate burglary and cover-up drew to a close, members of the Watergate Special Prosecution Force considered how to proceed against President Nixon. ${ }^{134}$ Al-

132 See N.Y. Penal Law $§ 195.00(2)$ (McKinney 1975) (misdemeanor crime of official misconduct for a public servant, acting with "intent to obtain a benefit or to injure or deprive another person of a benefit," to knowingly fail to perform a duty "clearly inherent in the nature of his office."). Many of the conflict of interest statutes contain criminal as well as civil penalties. See, e.g., MASs. ANN. LAws ch. 268A, \& 78 (Law Co-op. 1980).

${ }_{133}$ Most grand jury criminal investigations, however, will raise quantitative evidentiary problems, and if the official's misconduct is indictable, the criminality or noncriminality of that misconduct can only be determined at trial. Qualitative evidentiary problems are likely to occur less frequently, but when they do arise, the criminality of the official's misconduct depends on unsettled questions of law.

${ }_{134}$ For a brief history of the Watergate Special Prosecution Force, created in the Department of Justice to investigate and prosecute crimes arising from the June, 1972 burglary of the Democratic National Committee headquarters at the Watergate Hotel, see Watergate Special Prosecution Force Report 4-20 (U.S. Government Printing Office pub., 1975) [hereinafter WATERGate RePORT]. For an enlightening account of the conflicts among the prosecuting team regarding how to proceed against the President, see R. Ben-Veniste \& G. Frampton, Stonewall: The Real Story of the Watergate Prosecution 211-46 (1977). 
though all agreed that the evidence was quantitatively sufficient to indict the President for obstruction of justice and related crimes, ${ }^{135}$ Special Prosecutor Leon Jaworski doubted that a sitting president could constitutionally be charged with obstruction of justice, particularly when that conduct was the basis of an impeachment inquiry already initiated by the House Judiciary Committee. ${ }^{138}$ Applying the suggested distinction between the quantitative and qualitative evidentiary problems, ${ }^{137}$ the difficulty Jaworski saw in indicting the President can best be characterized as a qualitative evidentiary problem. Regardless of the strength of evidence that the President committed criminal misconduct, that misconduct might not have been indictable while he remained in office. ${ }^{138}$

In his concluding remarks to the grand jury, Jaworski advised against indicting the President because of the uncertainty on the immunity issue and the availability of the impeachment inquiry to determine if the President's misconduct justified removal from the office. ${ }^{139}$

195 See R. Ben-Veniste \& G. Frampton, supra note 134, at 226-27; L. JAworski, The Right and the Power: The Prosecution of Watergate 99 (1976).

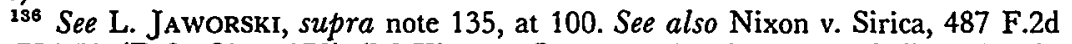
700, 756-58 (D.C. Cir. 1973) (McKinnon, J., concurring in part and dissenting in part) (positing that the proposition that a President may only be subject to the criminal law after impeachment essentially derives from implications inherent in the impeachment clause, contemporaneous views of the Framers, and the need for a President to remain free to fulfill constitutional duties); United States v. Nixon, the PresiDENT BEFORE THE SUPREME Court 319, 379-87 (L. Friedman ed. 1974) (quoting Brief for Richard M. Nixon, United States v. Nixon, 418 U.S. 683 (1974) (No. 731766)) (arguing that impeachment is the exclusive remedy for presidential criminal misconduct). But see id. at 209, 271 n.77 (quoting Brief for the United States, United States v. Nixon, 418 U.S. 683 (1974) (No. 73-1834)) (arguing that the Constitution does not warrant presidential immunity from the ordinary process of criminal law prior to impeachment and removal); Danielson, Presidential Immunity From Criminal Prosecution, 63 GEO. L.J. 1065, 1066-69 (1975) (questioning both the argument that the sequence of events in article I-impeachment, then criminal prosecution-indicates the Framers' intent that Presidents be immune from criminal prosecution while in office and the argument that since article II vests the entire executive power in one person, an incumbent President must be immune from criminal prosecution to ensure the proper functioning of the executive branch).

${ }^{137}$ See supra text accompanying notes 112-17.

${ }^{138}$ This qualitative evidentiary problem, however, differs from the one previously discussed of whether a campaign contribution is a benefit under the bribe receiving statute. See id. If the contribution was not a benefit, the public official could never be prosecuted for receiving the contribution. On the other hand, if the President was constitutionally immune from prosecution, his immunity presented a bar to prosecution only while he remained in office. See L. JAwORSKI, supra note 135, at 100 (Special Prosecutor Leon Jaworski discussing his doubts concerning the indictability of a sitting president for the offense of obstruction of justice).

139 Jaworkki's recommendation came after exhaustive legal research and consideration of the grave Constitutional issues involved:

It will not be necessary to weigh the evidence to determine whether there 
Jaworski recommended instead that the grand jury transmit evidence of the President's involvement in the cover-up in a report to the House Judiciary Committee. ${ }^{140}$ Jaworski further requested that the grand jury authorize the naming of the President as an unindicted coconspirator in connection with the trial of seven former members of his staff and election campaign indicted by the grand jury. ${ }^{141}$ The grand jury agreed with both recommendations. ${ }^{142}$

Determining the contents of the Watergate report was one of the most divisive issues faced by the prosecution team. Jaworski concluded that the best way to ensure transmittal of the grand jury's evidence to Congress was to prepare a report that could not be interpreted as accusing the President of misconduct and proposed that the report transmit evidence without summary or analysis. ${ }^{143}$ It is understandable why Jaworski favored this approach. If a report reveals only evidence, no explicit grand jury accusation of misconduct is made and the report is

is probable cause to indict. The legal doubt that a sitting President is indictable for offenses of the type considered by you is so substantial that indictment of the President should be ruled out. It would not be responsible conduct in my opinion to return an indictment against the President in the present uncertain state of the law, only to learn in the end that the United States Supreme Court holds such action to be unconstitutional. The trauma the nation would suffer in the interim, let alone the scars such actions would leave on the institution of the Presidency, renders such action inadvisable, regardless of whether the evidence otherwise would warrant it.

J. Doyle, Not Above the Law: The Battles of Watergate Prosecutors CoX AND JAwORSKI 307-08 (1977). Jaworski added that there was another sound reason for not proceeding against the President. The House impeachment inquiry was well under way, he said, and "[The House] is the appropriate body under the Constitution, in my view, for examining in the first instance evidence relating to the President to determine whether he should be charged with conduct justifying impeachment and removal from office." Id. at 308; see also R. BEN-VEnisTE \& G. FRAMPTON, supra note 134, at 244, 253 (discussing Jaworski's belief that it "would not be responsible conduct" to indict the President); L. JaworsKI, supra note 135, at 100 (concluding that to indict an incumbent president would result in delay in determining culpability and would result in a denial of the president's right to a fair trial).

110 R. Ben-Veniste \& G. Frampton, supra note 134, at 246-47; J. Doyle, supra note 139 , at 308 .

161 R. BEN-VEniste \& G. Frampton, supra note 134, at 246-47. The constitutionality of that action was challenged by the President in his brief appealing the district court order that required him to provide subpoenaed evidence, including tapes of oval office conversations, to the Special Prosecutor. See United STates v. Nixon, The President Before the Supreme Court 319, 387-95 (L. Friedman ed. 1974) (quoting Brief for Richard M. Nixon, United States v. Nixon, 418 U.S. 683 (1974) (No. 73-1766)). In affirming the district court's order, the Supreme Court did not decide the coconspirator issue. See Nixon, 418 U.S. at 687 n.2.

142 R. BeN-VENISTE \& G. FRAMPTON, supra note 134, at 246-47.

143 Id. at 241-42; L. JAwORSKI, supra note 135, at 101. It has been tantalizingly suggested that Jaworski's insistence on this form of report was based on ex parte contacts with Judge Sirica. See J. Doyle, supra note 139, at 285. 
less susceptible to the objection that it is indistinguishable from an indictment. Furthermore, since the grand jury was not seeking the report's public distribution, but merely the report's transmittal to Congress, the public could never mistake the report for the equivalent of a criminal accusation.

Other members of the prosecution team, however, favored a more comprehensive report than Jaworski had suggested. The report they envisioned would not only transmit evidence, but would summarize and comment on the evidence and state the "theory of the case" against the President. ${ }^{144}$ The report would

show how the tapes and other evidence fit together and demonstrate that the President had been trying to hold the cover-up together in March and April of 1973. The report could also juxtapose the President's public statements denying knowledge of the cover-up with evidence from the tapes showing he really knew far more. ${ }^{145}$

The report ultimately prepared by the Watergate grand jury represented a compromise between Jaworski and his staff that the prosecutors referred to as the "road map."146 The road map did not comment on the evidence against the President or offer conclusions. Instead, it was a list of short statements that detailed the President's involvement in the cover-up, followed by references to supporting evidence transmitted to the Committee. ${ }^{147}$ Its drafters intended the road map to "serve as

144 R. Ben-Veniste \& G. Frampton, supra note 134 , at 241-42.

145 Id. at 242.

148 Id. at $242-43$.

${ }^{147}$ Id. at 247. The report has never been made public, but in his book reviewing the Watergate criminal investigation, the press spokesperson for the Special Prosecutor's Office provides the most detailed published account of how it was organized:

It was a simple document, fifty-five pages long, with only a sentence or two on each of the pages. Each page was a reference to a piece of evidence-sentences from one of the tape recordings, quotations from grand jury testimony.

This is how the road map worked: One page might say, "On March 16,1973 , E. Howard Hunt demanded $\$ 120,000$." Then it would list page references to grand jury testimony from witnesses who saw Hunt's blackmail note and references to the tapes where Hunt's demand was discussed. The grand jury transcripts and the tape transcripts would be included. The next page might say, "On March 21, 1973, John Dean told President Nixon that Hunt had demanded $\$ 120,000$ and that he estimated Hunt and the other Watergate defendants would 'cost' a million dollars in the next two years." More grand jury and tape transcript page references. The next page might say, "President Nixon responded, 'For Christ's sake, get it" "; and there would be further references to the tapes.

J. Doyle, supra note 139, at 290-91 (footnote omitted). 
a do-it-yourself kit for the Judiciary Committee, helping it to reassemble the individual pieces of grand-jury testimony and other evidence into a coherent theory of a criminal case . . ."148 Thus, while the Watergate report stopped short of directly accusing the President of misconduct, "[a]n inexorable logic marched through its pages. The conclusion that the President of the United States took part in a criminal conspiracy became inescapable."149

In June, 1972 Report, District Judge Sirica considered whether to transmit the Watergate report to the House Judiciary Committee and concluded that it was necessary to decide two issues to answer that question. ${ }^{180}$ First, Judge Sirica considered whether the grand jury has the "power to make reports and recommendations."151 Judge Sirica answered that question in the affirmative ${ }^{162}$ and supported his conclusion with federal case law acknowledging the grand jury's reporting authority. ${ }^{163} \mathrm{He}$ then distinguished the Watergate report from the objectionable features of reports disapproved in two other federal cases: ${ }^{154}$

The Report ... draws no accusatory conclusions. It deprives no one of an official forum in which to respond. It is not a substitute for indictments where indictments might properly issue. It contains no recommendations, advice or statements that infringe on the prerogatives of other branches of government. Indeed, its only recommendation is to the Court, and rather than injuring separation of powers principles, the Jury sustains them by lending its aid to the House in the exercise of that body's constitutional jurisdiction. It

148 R. Ben-VEniste \& G. FRAmpton, supra note 134 , at 242-43.

149 J. DoyLE, supra note 139, at 291.

180 June, 1972 Report, 370 F. Supp. at 1221-22.

151 Id. at 1221.

162 Id. at 1226 .

${ }^{153}$ Id. at 1223-24 (citing In re Presentment of Special Grand Jury Impaneled January, 1969, 315 F. Supp. 662 (D. Md. 1970); United States v. Cox, 342 F.2d 167 (5th Cir.), cert. denied, 381 U.S. 935 (1965); In re Grand Jury Proceedings, 479 F.2d 458 (5th Cir. 1973); In re Johnson, 484 F.2d 791 (7th Cir. 1973)).

${ }_{154}$ The first case, In re United Elec., Radio \& Mach. Workers, 111 F. Supp. 858 (S.D.N.Y. 1953), involved a report critical of private persons and is discussed supra at note 10. The second case, Hammond v. Brown, 323 F. Supp. 326 (N.D. Ohio), aff'd, 450 F.2d 480 (6th Cir. 1971), concerned a report that rendered moral and social judgments on the policies, attitudes, and conduct of those connected with the shootings at Kent State University in 1970 . The report contained derogatory accusations directed towards the university administration, faculty, and students. The Hammond court was concerned that such a report presented separation of powers problems. As Judge Sirica stated, "Hammond relied upon Ohio law for the proposition that the grand jury lacked statutory authority to return a report of that kind in that case, noting further that common-law crimes and common-law criminal procedures were nonexistent in Ohio." June, 1972 Report, 370 F. Supp. at 1225 (citation omitted). 
renders no moral or social judgments. The Report is a simple and straightforward compilation of information gathered by the Grand Jury, and no more. ${ }^{185}$

Satisfied that the grand jury acted properly in preparing its report, Judge Sirica turned to the second threshold issue raised by the report: "whether the Court has power to disclose [a grand jury report] and, if so, to what extent."168 Having rejected the argument that traditional justifications for grand jury secrecy prevented release of the report, ${ }^{167}$ Judge Sirica determined that since the report was a proper exercise of the reporting function, public release appeared to be appropriate. The grand jury's request seemed even more reasonable as it requested transmittal of its report only to the House Judiciary Committee "for a decision on what action, if any, might be warranted in the circumstances."188

Judge Sirica balanced a variety of competing interests in deciding whether to transmit the Watergate report to Congress ${ }^{\mathbf{1 5 9}}$ and concluded

$18 s$ June, 1972 Report, 370 F. Supp. at 1226.

${ }_{158}$ Id. at 1221-22.

187 Id. at $1227-30$.

${ }^{158} I d$. at 1221. The language quoted in the text is Judge Sirica's characterization of the grand jury's request. Two former members of the Watergate Special Prosecution Force noted that the request was phrased slightly differently and argued that the actual request reflected an important clue as to the grand jury's intention if the President was not impeached. They noted that when a draft of the report was submitted to the grand jury, the jurors insisted on only one change:

The preamble, as approved by the jurors, was changed to say that they would "presently" defer to the Judiciary Committee and allow the committee to decide what should be done "at this time." This language was a none-too-subtle hint to the Congress that the jury would still be around to move against the president if the politicians faltered. Strangely, when the preamble was eventually made public, none of the media commentators remarked on these highly pregnant phrases.

R. Ben-Veniste \& G. Frampton, supra note 134, at 247.

${ }^{169}$ See June, 1972 Report, 370 F. Supp. at 1226-30. A balancing test for deciding whether to release grand jury reports had been suggested in a Fifth Circuit case, cited by Judge Sirica. There, the court summarized several factors to be considered in making release decisions:

[W] hether the report describes general community conditions or whether it refers to identifiable individuals; whether the individuals are mentioned in public or private capacities; the public interest in the contents of the report balanced against the harm to the individuals named; the availability and efficacy of remedies; whether the conduct described is indictable.

In re Grand Jury Proceedings, 479 F.2d 458, 460 n.2 (5th Cir. 1973). See also Comment, supra note 6 , at 725 (arguing that a distinction should be made between reports in which individuals are named and reports that relate to general conditions in public institutions); Comment, supra note 5, at 353 (proposing a "reputation" distinction that differentiates between reports that censure institutions that depend on their reputations, such as universities, and those that do not, such as municipal water departments). 
that its transmittal to the House Judiciary Committee was "eminently proper, and indeed, obligatory." $160 \mathrm{He}$ emphasized that the report concerned the conduct of a public official ${ }^{\mathbf{1 6 1}}$ and that the public interest in transmittal was substantial since "[i]t would be difficult to conceive of a more compelling need than that of this country for an unswervingly fair [impeachment] inquiry based on all the pertinent information."162 Indeed, the public interest in the report was so significant that Judge Sirica suggested that the grand jury might even have been justified in seeking its public release. ${ }^{163}$

The potential harm of the report to the President seemed minimal when balanced against the public interest in disclosure. Judge Sirica, who had noted earlier in the opinion that the report was not a "substitute for indictments where indictments might properly issue," emphasized that the President did not object to release and was free to challenge any material in the report that might be used against him in the impeachment inquiry. ${ }^{165}$ The President, therefore, was not "left without a forum in which to adjudicate any charges against him that might employ Report materials."

\section{The Alaska Impeachment Report}

\section{The Grand Jury Investigation and Report}

The report that recommended the initiation of impeachment proceedings against the Governor of Alaska arose from a grand jury investigation into the award of a state lease for office space. ${ }^{167}$ The investigation centered on allegations that the Governor's office had manipulated the state's competitive bidding process to ensure that the lease was awarded to a partnership including a major gubernatorial campaign fundraiser. ${ }^{168}$

160 June, 1972 Report, 370 F. Supp. at 1227.

181 Id.

162 Id. at 1230.

${ }^{183}$ Id. The grand jury, of course, had requested transmittal only to the House Judiciary Committee, which would use the evidence in the report in deciding whether there were sufficient grounds for impeachment and a trial in the Senate. Since public disclosure of the report may have been justified, Judge Sirica reasoned that there was "certainly ample basis for disclosure to a body that in this setting acts simply as another grand jury." Id.

${ }^{164}$ Id. at 1226; see also supra text accompanying note 123 (grand jury's reporting function distinguished from indicting function and praised for its ability to hold public officials accountable for actions that do not rise to the level of indictable offenses).

165 June, 1972 Report, 370 F. Supp. at 1227.

${ }_{180}$ Id.

${ }^{167}$ See supra note 16 and accompanying text.

${ }^{168}$ Id. 
The Governor's Chief of Staff and the fundraiser were two grand jury witnesses. Primarily as a result of their testimony, the grand jury learned the following about the lease award: in late September of 1984, the Governor sent the draft bidding documents for the lease to the fundraiser at the fundraiser's request; ${ }^{169}$ when the documents were sent, the specifications for the lease award had been approved by the Governor's office but the documents had not been released to other prospective bidders; ${ }^{170}$ in early October of 1984 , the Governor attended a meeting with his Chief of Staff during which the fundraiser requested changes to the draft bidding documents to ensure that his partnership would be the only eligible bidder for the lease ${ }^{171}$ and that the effect of the requested changes was discussed during that meeting;, ${ }^{172}$ the Ghief of Staff left the meeting with the understanding that he was to bring about the requested changes and that he did so with the encouragement and support of the Governor; ${ }^{173}$ the changes were made, the fundraiser's partnership was the only eligible bidder, and the lease was awarded to the partnership. ${ }^{174}$

This evidence raised the possibility that the Governor had committed two crimes in connection with the lease award and his grand jury testimony. The first was official misconduct by encouraging his Chief of Staff to bring about the changes requested by the fundraiser. ${ }^{175}$ The second was perjury by testifying before the grand jury that he had no recollection of the early October meeting and other key events surrounding the lease award. ${ }^{176}$

169 AlASKa ImPEACHMENT REPORT, supra note 16, at 14-15, 38-39.

170 Id. at 14-15, 36-37.

171 Id. at 39-42. The changes narrowed the geographical area in which the state was seeking office space and required the state to assume occupancy earlier than originally specified in the draft documents. These changes precluded new construction to meet the state's request for office space and ensured that the fundraiser's partnership would be the only eligible bidder. See id.

${ }^{172} I d$. at 41,64 . The Chief of Staff testified that the only reason given by the contributor in support of the requested changes was that it would eliminate other potential bidders for the lease. Id. at 41 .

${ }^{173}$ Id. at 3-4, 7, 62-63.

174 Id. at $42-50$.

175 The crime of official misconduct is committed under Alaska law if a public servant, with intent to obtain a benefit, knowingly performs an unauthorized act relating to her office or fails to perform a duty imposed by law or inherent in the nature of her office. Alaska STAT. $\S 11.56 .850$ (1983). The definition of benefit is broad enough to include any advantage to a third person pursuant to the desire of the public servant. See AlaSKa STat. $\$ 11.81 .900(b)(2)(1983)$ ("[B]enefit means a present or future gain or advantage to the beneficiary or to a third person pursuant to the desire or consent of the beneficiary.").

${ }^{178}$ Perjury is committed under Alaska law if a person "makes a false sworn statement which the person does not believe to be true." ALASKa STaT. § 11.56 .200 (1983). The definition of statement includes representations of a person's state of mind. 
At the conclusion of the investigation, the two lead prosecutors, Special Counsel George Frampton, Jr. ${ }^{177}$ and the state's Chief Prosecutor, Daniel W. Hickey, addressed the grand jurors and offered them two options for resolving their case against the Governor: indict the Governor, or issue a public report on their investigation. ${ }^{178}$ To assist the grand jury in considering the first option, the prosecutors circulated a draft indictment that charged the Governor with one count of official misconduct and six counts of perjury. ${ }^{179}$ The prosecutors also provided the grand jury with the first sections of a draft report. ${ }^{180}$

ALASKA STAT: $\S 11.56 .240(1)$ (1983).

177 Frampton's appointment as Special Counsel occurred thirteen years after he argued unsuccessfully with Jaworski for a report spelling out the "theory of the case" against President Nixon. See supra text accompanying notes 143-44. In the Alaska investigation, Frampton had the authority to participate with the state's Chief Prosecutor in all decisions that concerned the investigation and to present the grand jury with independent advice and recommendations at the conclusion of the evidence. See Letter from Norman C. Gorsuch, Attorney General, to George Frampton (May 23, 1985) [on file with the University of Pennsylvania Law Review].

The appointment of a Special Counsel in the case was no doubt influenced by the fact that in Alaska the Attorney General is appointed by the Governor and serves at his pleasure. See Alaska Const. art. III, $\S 25$. The state's Chief Prosecutor, in turn, is appointed by the Attorney General. See Alaska STAT. $\$ \S 39.25 .020,44.23 .010$ (1986). The involvement of an outside Special Counsel in the case minimized the concern that the Chief Prosecutor's handling of the investigation might have been influenced by his position being ultimately dependent on the continued support of the Governor. See also In re Grand Jury Proceedings for the Grand Jury Convened in Juneau, Alaska, Commencing April 24, 1985, Transcript of Grand Jury Proceedings, June 1921, 1985, at 2075-76 (Alaska Super. Ct.) [hereinafter Grand Jury Transcript] (Frampton describes himself as an outsider unfamiliar with the facts or politics surrounding the investigation.)

This Article can quote directly from the grand jury proceedings because virtually the entire grand jury transcript was made public by the superior court several days after the report was released. Only the names of the jurors, confidential exibits, and items such as business notebooks were kept from the public. See In re the Grand Jury for the First Judicial District at Juneau for the Term of Proceedings Commencing in April, 1985, No. 1JU-85-1600 Civ. (Alaska Super. Ct. July 10, 1985) (mem.).

178 Grand Jury Transcript, supra note 177, at 2522-23. Chief Prosecutor Hickey also briefly discussed a third option: an indictment followed by an abbreviated report. Id.

${ }^{179} \mathrm{Id}$. at $2538-39,2547-64$. The draft indictment alleged that the Governor committed official misconduct by knowingly failing to perform

a duty clearly inherent to the nature of his office, that duty being to serve the public loyally, honestly, and faithfully ahead of any and all private interests and that he breached this duty by encouraging that action be taken by [his Chief of Staff] to eliminate competition for [the state lease] with the intent to obtain a benefit for other persons, knowing when he did so that he was placing the private interests of these persons above the interests of the public.

Id. at 2562. The six draft perjury counts alleged that the Governor testified falsely when he told the grand jury he had no recollection of the early October meeting with the contributor and other key events concerning the lease award. Id. at 2547-62.

180 Id. at 2531-38. The contents of the draft report had been suggested by the 
In addition to distributing the draft indictment and report, the prosecutors presented their separate views on the two alternatives. ${ }^{181}$ Neither prosecutor instructed the grand jury to consider issuing a report only if it determined the Governor's conduct was not indictable. Instead, Frampton told the grand jury that the Governor could be indicted on five of the proposed counts ${ }^{182}$ but nevertheless recommended that a report be issued. ${ }^{183} \mathrm{He}$ drew a parallel to the Watergate investigation $^{184}$ and told the grand jury it faced the same decision as the Watergate grand jury: "to indict a chief executive or take some other course of action instead that would attempt to hold him accountable for serious criminal conduct."185 Essentially, Frampton asked the grand jury to make a public policy decision: when there is sufficient evidence to indict a sitting governor for criminal misconduct, is the public interest better served by a comprehensive report that publicizes the misconduct than by a prosecution?

Frampton characterized a report as "an option which accomplishes more of the goals . . . we would all like to see accomplished in this case, principally to hold the person who did wrong accountable for that and, secondarily, to make sure that the facts are eventually made available to the public in an authoritative fashion."188 The report, he argued, placed "the ultimate issue of accountability in the place where it ultimately belongs in the case of the chief executive of the state, which is with the public...."187 A report "had the advantage[] of getting all of the facts out in a fairly organized manner and getting them out

grand jury little more than a week earlier when it decided to grant immunity to the Governor's Chief of Staff to compel his testimony and, following that testimony, to issue a public report of its investigation. $I d$. at 2161, 2162-70, 2175. When the grand jury decided to compel the testimony of the Chief of Staff, it also recognized that his testimony might lead to the initiation of criminal charges against other persons. Id. at 2175-78.

${ }^{181}$ Id. at 2566-89 (Frampton's views), 2589-96 (Hickey's views).

182 Frampton stated that it was "absolutely clear from the evidence" that the Governor had committed crimes. Id. at 2567. He concluded that there was insufficient evidence to support an indictment on two of the perjury counts, but he told the grand jury that the remaining four perjury counts and the count of official misconduct were indictable. Id. at 2572, 2576-78.

The state's Chief Prosecutor never specifically stated whether he believed the evidence supported an indictment on any of the draft counts. However, in a subsequent characterization of his grand jury remarks, the Chief Prosecutor concluded that he had "generally stressed that the evidence supported the return of an indictment ...." Memorandum of Chief Prosecutor, supra note 17, at 17.

183 Grand Jury Transcript, supra note 177, at 2571.

184 Id. at 2566-68.

${ }^{188} \mathrm{Id}$. at 2567.

${ }^{186} \mathrm{Id}$. at 2586.

${ }^{187}$ Id. at 2587. 
quickly." 188 An indictment, on the other hand, would "basically bring the state government to a halt for the next year-to paralyze it ...."189

Although Frampton concluded that five of the seven proposed criminal counts were indictable, ${ }^{190}$ he worried that evidentiary considerations made the case not very "attractive" from the standpoint of obtaining a conviction. ${ }^{191} \mathrm{He}$ told the grand jury that an acquittal after a trial "would be the most disastrous result of all" and that "this is not the kind of case that anybody can afford have go to trial and not result in a conviction." 192 In response to a juror's question about the effect of an acquittal on a politician's reputation, ${ }^{193}$ Frampton replied that "[a]s a practical matter, acquittal would represent that [the politician] was vindicated and that it was prosecutorial over-reaching to charge him." ${ }^{\text {"194 }}$ Relying upon this fear of acquittal and the public interest in accountability, Frampton strongly advocated issuing a report despite the existence of sufficient evidence for indictment.

After deliberation, the grand jury followed Frampton's recommendation and decided to issue a report that "ha[d] some very specific and strong language in it."198 The grand jury requested that its report include a finding that the Governor and some members of his administration were unfit for public office and a recommendation that the legislature initiate impeachment proceedings against the Governor. ${ }^{196}$ The grand jury foreperson added that if a report that contained "very specific and strong language" was not within its powers, the grand jurors wanted to "reserve the right to change [their] minds."197 Prosecutors subsequently contended that this statement reflected the grand jury's readiness to indict the Governor if the court blocked publication of the report. $^{198}$ Interviews with the grand jurors also supported this

$188 I d$.

189 Id. at 2587-88.

180 Frampton told the grand jury that there was "certainly sufficient evidence. . . for someone to conclude beyond a reasonable doubt" that the Governor had committed perjury. Id. at 2584 .

191 Id. at 2578-83. Frampton's main concern involved the admissibility of evidence that the Governor's Chief of Staff lied to the investigators in an attempt to protect the Governor. He feared that since the Chief of Staff faced no charges of obstruction of justice or conspiracy, the most damaging evidence of the Governor's perjury would not reach the trial jurors. $I d$. at $2579-83$.

192 Id. at 2620.

103 Id. at 2622 .

194 Id. at 2623.

198 Id. at 2629.

198 Id. at 2630.

197 Id. at 2629-30.

198 Memorandum of Chief Prosecutor, supra note 17, at 20. 
interpretation. ${ }^{199}$

The Alaska Impeachment Report never states that the Governor's misconduct was noncriminal. Instead, it suggests that the misconduct was criminal and implies that the grand jury decided to forego prosecution to more effectively promote the seven goals cited in the report's introduction. ${ }^{200}$ The report contains a finding that the Governor is unfit for public office ${ }^{201}$ and provides a detailed summary of the evidence heard by the grand jury. ${ }^{202}$ The summary includes seven excerpts from the Governor's testimony in which he failed to recall key events pertaining to the lease, including the October meeting. ${ }^{203}$ A summary of key evidence calling into question the veracity of the Governor's claims of lack of recollection accompanies each excerpt. ${ }^{204}$ The text of the report, as a whole, communicates the strong implication that the Governor committed perjury. ${ }^{205}$ The report can also be read to accuse the Governor of the crime of official misconduct, but, in this instance, the inference of criminality is not as strong as the suggestion of perjury. ${ }^{206}$

${ }^{199}$ See Inside Look at the Grand Jury, Fairbanks Daily News-Miner, Aug. 8, 1985, at 1, col. 1, 15, cols. 2, 4 (remarks of Al Baffone, Sr., business manager and secretary treasurer of Public Employees Local 71 in Anchorage) ("[Fourteen jurors] voted to issue their scathing report. The 15th juror wanted to indict the governor. There was, as the jurors put it, 'no one for innocent.' . . . Because the jurors didn't believe [the Governor's] testimony, they were prepared to indict him for perjury if their report had been suppressed.").

200 - To be positive, constructive and impartial in our outlook and actions;

-To best serve the publicinterest, as viewed in the widest sense;

-To hold elected and appointed public officials accountable for their actions;

-To encourage changes in public policy, regulations and laws so as to better protect the public interest in the future;

-To enhance public awareness of the facts of wrongdoing or abuse of office by public officials, to the greatest extent possible;

-To make sure insofar as possible that justice is served; and

-To provide a deterrent against wrongdoing and abuse of office by public officials in the future.

ALASKA IMPEACHMENT REPORT, supra note 16, at 5-6.

201 Id. at $1-6$.

202 Id. at 21-67.

203 Id. at 59-67. At least one court has addressed the question whether a grand jury report can contain transcripts of grand jury testimony. See McClatchy Newspapers v. Superior Ct., 209 Cal. Rptr. 598, 603 (Cal. App. 1985) (holding that a court could not refuse to file a grand jury's report that included transcripts of testimony of witnesses who appeared before it during the investigation).

204 AlASKa IMPEACHMENT REPORT, supra note 16, at 59-67.

205 The grand jury expressed "grave concerns" about the Governor's inability to recall key events about the lease award and characterized his testimony as reflecting "a lack of candor and a disrespect for the laws of this state." Id. at 14.

${ }^{200}$ The grand jury observed that the conduct undertaken to favor the campaign fundraiser might constitute the crime of official misconduct under Alaska law but concluded that the statute was "potentially inadequate to deter" the conduct investigated 
By publicly accusing the Governor of misconduct and by implying that his misconduct may have been criminal, the Alaska Impeachment Report exemplifies Judge Fuld's concern that accusation by indictment and report are indistinguishable. On the other hand, Judge Sirica's characterization of the Watergate report makes it the paradigm of a report that withstands Judge Fuld's concern. However, some aspects of the reports are not as dissimilar as they initially appear.

\section{The Watergate and Alaska Impeachment Reports Compared}

Despite superficial dissimilarities, the Watergate and Alaska Impeachment Reports are substantively similar in that both reveal suspected criminal misconduct by a chief executive. On the other hand, the reports were released to different audiences and, most importantly, differ in the reasons each prosecutor advanced for issuing a report as an alternative to prosecution. Whereas Jaworski's preference for a report was driven by the concern that a sitting president was immune from prosecution, Frampton's preference was based on his belief that a public report was the faster and more effective route to holding the Governor accountable for violating the public trust. ${ }^{207}$

The Alaska Impeachment Report accuses the Governor of misconduct in unmistakable terms by criticizing the Governor for his lack of candor and disrespect for state law. ${ }^{208}$ Similarly, although Judge Sirica emphasized that the Watergate Report was a "simple and straightforward compilation of information" that drew "no accusatory conclusions," 200 the compilation of evidence in the Watergate road map stated "a coherent theory of a criminal case"210 against the President that the

by the grand jury for two reasons. Id. at 9 . First, the grand jury noted that the statute might require a showing that a defendant undertook an action to benefit a private person knowing that the action was inconsistent with the state's best interest. The grand jury concluded that such a "showing may be difficult or impossible to make even when it is clear that a public official has acted with primary intent to benefit a private person, if that action could later, in hindsight, be rationalized as consistent with some governmental policy." Id. Second, the grand jury concluded that "the criminal process inevitably tends to single out for responsibility those who take the most visible actions-in this case, [the Governor's Chief of Staff]." Id. The grand jury noted that responsibility for that action "must rightfully be shared, as here, by others who approved the action and on whose behalf the action was taken." Id. Thus, while the grand jury acknowledged that the Governor's conduct potentially did not come within the coverage of the crime of official misconduct, it never concluded that the evidence was insufficient to warrant indictment.

${ }^{207}$ It is doubtful whether the goals Frampton advanced are served best by the issuance of a public report as an alternative to the indictment of a public official. See infra notes 243-60 and accompanying text.

${ }^{208}$ See supra note 16 and accompanying text.

208 June, 1972 Report, 370 F. Supp. at 1226.

210 See R. BEN-VENISTE \& G. FRAMPTON, supra note 134, at 242-43. 
prosecutors $^{211}$ and grand jurors ${ }^{212}$ believed was sufficient for indictment. ${ }^{213}$ Moreover, although Judge Sirica noted that the report was "not a substitute for indictments where indictments might properly issue,"214 it is unlikely he meant that the evidence detailed in the road map was quantitatively insufficient to support a prosecution. ${ }^{\mathbf{2 1 5}}$ Instead, the comparison to such a situation more likely reflected Judge Sirica's belief that the evidence was qualitatively insufficient to indict the President while in office. ${ }^{216}$

In addition, both reports implied that the chief executive should be impeached. ${ }^{217}$ Although Judge Sirica stressed that the Watergate report contained "no recommendations, advice or statements that infringe on the prerogatives of other branches of government,"218 it was unneces-

211 See id. at 226.

212 The decision of the grand jurors to authorize the naming of the President as an unindicted coconspirator supports the conclusion that they believed he committed criminal misconduct. See supra text accompanying note 141; see also R. BEN-VENISTE \& G. FRAMPTON, supra note 134, at 250-54 (jury's actions had the same impact as a formal accusation of the President).

213 Indeed, this was precisely the conclusion the drafters of the report wished to convey. See supra text accompanying note 148; see also Haldeman v. Sirica, 501 F.2d 714, 716 (D.C. Cir. 1974) (MacKinnon, J., dissenting in part) ("The process of composing the [road map] and selecting the evidence supporting it necessarily reflects a conscious and focused judgment by the grand jury on the credibility of witnesses and the inferences to be drawn from the totality of evidence presented to it.").

214 June, 1972 Report, 370 F. Supp. at 1226.

215 That interpretation is particularly unlikely since a defendant is precluded from challenging a federal indictment based on the claim that there was insufficient evidence to indict. See infra note 236.

${ }^{216}$ The question of whether the Watergate report was a "substitute for indictments where indictments might properly issue" highlights an ambiguity in defining the existence of the reporting authority by a bright line rule of whether or not the official could have been indicted. See supra text accompanying notes 119-24. In one respect the Watergate report may have revealed unindictable misconduct. If the President was immune from prosecution, his misconduct was not indictable while he remained in office. However, after that point, the President's misconduct was indictable. This ambiguity is unlikely to present substantial problems in defining the scope of the reporting function by reference to the question of "indictability," since it is doubtful whether any public official besides the president can claim immunity from prosecution while in office. See infra note 223.

217 It had previously been held that a federal grand jury report that recommends action within the exclusive control of the executive or legislative branches violates the separation of powers doctrine. See, e.g., In re United Elec., Radio \& Mach. Workers, 111 F. Supp. 858, 864-65 (S.D.N.Y. 1953). The separation of powers objection to reports that recommend action within the exclusive conduct of the legislative or executive branches is not persuasive. See 1 S. BEALE \& W. BRYSON, supra note 7, at $\S 3: 01$ (The grand jury is not a governmental body, and even were one to consider it an arm of the court, a report should be no more suspect than a judicial opinion that calls for legislative action.); McClellan, The Organized Crime Act (S. 30) or Its Critics: Which Threatens Civil Liberties?, 46 NOTRE DAME LAw. 55, 78 (1970) (The grand jury lacks power to implement its decision and therefore poses no threat to the separation of power.).

${ }^{218}$ June, 1972 Report, 370 F. Supp. at 1226. 
sary for the Watergate grand jury to recommend the initiation of impeachment proceedings since the proceedings were ongoing during the grand jury investigation. Furthermore, the Watergate report subtly stated that the grand jury would "presently" defer to the impeachment inquiry, suggesting that the grand jury would indict the President were he not impeached. ${ }^{219}$ Similarly, the Alaska grand jury recommended that the legislature begin impeachment proceedings against the Governor, finding the Governor unfit for public office. ${ }^{20}$ Thus, although neither report specifically recommended impeachment, both grand juries intimated that impeachment was appropriate.

While the reports are substantively similar, they differ in the method of release. The Watergate report was transmitted only to the House Judiciary Committee, while the Alaska report was publicly released. Transmittal of the Watergate report to the House Judiciary Committee provided the President with the opportunity to respond to the grand jury's evidence in an adversarial forum in which his accusers would be required to establish that his misconduct warranted impeachment. Although the Alaska grand jury recommended the creation of an identical adversarial forum for the Governor by calling for the initiation of impeachment proceedings, the Alaska legislature could have ignored the grand jury's recommendation. ${ }^{221}$

The most significant difference between the reports was the prosecutors' reasons in each investigation for recommending against indictment and in favor of a report. Jaworski argued against indictment primarily because of the concern that the President was immune from prosecution, ${ }^{222}$ whereas Frampton believed that a report offered a better means of meeting the public interest in the accountability of public officials.

Jaworski's concerns were rooted in the uncertainty of the law that surrounds presidential immunity from prosecution. ${ }^{223}$ That uncertainty,

218 See supra note 158.

220 See supra note 16.

221 If the impeachment proceedings were not initiated, the Governor's only opportunity to respond to the report would have been in the public forum or through a motion to expunge the report.

${ }^{222}$ See supra text accompanying note 139.

${ }^{228}$ The argument that public officials subject to impeachment are constitutionally immune from prosecution while in office was rejected when raised by United States Senators, see United States v. Brewster, 408 U.S. 501, 520 (1972); Gravel v. United States, 408 U.S. 606, 615-16 (1972), and federal judges, see United States v. Claiborne, 765 F.2d 784, 789 (9th Cir. 1985), cert. denied, 106 S. Ct. 1636 (1986); United States v. Hastings, 681 F.2d 706, 709-12 (11th Cir. 1982), cert. denied, 458 U.S. 1203 (1983); United States v. Isaacs, 493 F.2d 1124, 1140-44 (7th Cir.), cert. denied, 417 U.S. 976 (1974).

In their brief in United States v. Nixon, the Watergate prosecutors did not concede 
in the context of the Watergate grand jury investigation, seems sufficiently compelling, by itself, to have justified the decision to forego indicting the President in favor of transmitting key evidence of his misconduct to the impeachment committee.

If the impeachment proceedings were the only available forum for determining the President's responsibility for criminal misconduct, transmittal of the Watergate report to Congress promoted three important public interests. First, it furthered the public's right to know about the President's misconduct since the grand jury's evidence inevitably would be revealed during the impeachment inquiry. Second, as noted by Judge Sirica, the evidence transmitted in the Watergate report helped to ensure "an unswerving[ly] fair [impeachment] inquiry based on all the pertinent information."224 Third, even if the President's misconduct warranted a criminal prosecution, such a proceeding was impossible while he remained in office. Therefore, by aiding the impeachment inquiry, the grand jury acted to expedite the President's prosecution.

Moreover, the public interest. would not have been effectively served by an indictment. Although the theory of the case would have been revealed to the public, there was the risk that the President would never be held accountable for criminal misconduct in either the impeachment inquiry or a prosecution. The impeachment hearings might have faltered for lack of the grand jury's evidence, ${ }^{225}$ and the prosecutors might have been unable to use that evidence in a criminal trial since the indictment might have been dismissed due to the immunity issue.

Espousing different reasons than those expressed by Jaworski in the Watergate inquiry, Frampton, during the Alaska investigation, also argued against indictment and in favor of a report. Frampton was not concerned that the Governor was immune from prosecution; ${ }^{226}$ instead,

the immunity issue, noting that "[t]he Constitution . . . contains no explicit Presidential immunity from the ordinary process of the criminal law prior to impeachment and removal, and there are substantial arguments that an implicit immunity is likewise not warranted by the Constitution." United States v. Nixon, The President Before THE SUPREME CoURT, supra note 141, at $271 \mathrm{n} .77$ (quoting Brief for United States, United States v. Nixon, 418 U.S. 683 (1974) (No. 73-1834)); see supra note 139.

224 June, 1972 Report, 370 F. Supp. at 1230.

${ }_{225}$ The impeachment proceedings were off to a slow start as the Watergate prosecutors considered how to proceed against the President, who refused to transmit subpoenaed evidence to Congress. Prosecutors feared that without congressional access to the grand jury's evidence and road map the "momentum for impeachment might be shattered no matter how strong the evidence." R. BEN-VENISTE \& G. FRAMPTON, supra note 134, at 241.

${ }^{228}$ Frampton told the grand jury that there was no constitutional bar to indictment. See Grand Jury Transcript, supra note 177, at 2568. 
Frampton favored a report as a more effective alternative than a prosecution for holding the Governor acountable for a criminal violation of the public trust. He argued that a report could immediately hold the Governor accountable and would avoid the possibility of the "most disastrous result of all": the Governor's acquittal. ${ }^{227}$

When a grand jury investigation establishes an indictable violation of the public trust, the grand jury may view the official's prompt removal as a more important priority than prosecution. Particularly in cases that involve high public officials, the desire to impose criminal sanctions may seem secondary to an assurance that the official can no longer violate the public trust. Frampton's remarks to the grand jury reflected these concerns. Nevertheless, as will be discussed in Part III of this Article, these interests are not best protected when a report is used as an alternative to a prosecution.

\section{Defining the Scope of the Reporting Function}

The preceding sections discussed the competing public and private interests implicated by grand jury reports that reveal violations of the public trust. The Article concludes by reviewing three categories of reports to suggest the appropriate scope of the reporting authority.

\section{A. Reports Revealing Violations of the Public Trust That Are Not Indictable}

\section{Qualitative Insufficiency}

The argument in favor of the reporting function is strongest when the grand jury uncovers a violation of the public trust that is not regulated by the criminal law, and a report reveals that violation without an implication of criminal misconduct. This type of report exposes violations of the public trust where evidence of wrongdoing is qualitatively insufficient to establish a crime, and thus the grand jury is unable to reveal the official's misconduct by initiating a prosecution. ${ }^{228}$ Such a

${ }^{227}$ See supra text accompanying notes 193-94.

${ }^{228}$ An example of misconduct that can be revealed in this type of report is illustrated by a variation on the campaign contribution hypothetical discussed earlier in the Article. See supra text accompanying note 4.

Assume that a grand jury investigates allegations that a public official took a discretionary action to benefit a campaign contributor in return for a monetary bribe. Assume further that reported campaign contributions are specifically excluded from the coverage of the bribery statute and that the investigation establishes that a contribution, but nothing else, was received by the official as a quid pro quo for the action. If the official placed the interests of the contributor above the interests of the public in taking the action and no other criminal statute regulates the official's conduct, a report of the 
report furthers the public interest since it publicizes the official's misconduct and thereby holds the official accountable under a stricter standard of conduct than that required by the criminal law. The issuance of the report is also consistent with the historical role of the grand jury as a citizen watchdog over both noncriminal and criminal misconduct in government.

The concern that a grand jury report is indistinguishable from a criminal accusation does not need to attach to reports issued because of the qualitative insufficiency of evidence. Since the misconduct revealed by the report is not covered by the criminal law, any possible public confusion about the criminal nature of the misconduct can be eliminated by including in the report a finding that explicitly exonerates the official of criminal misconduct. ${ }^{229}$

The objection that the reporting function deprives public officials of a forum in which to respond to the grand jury's findings can be addressed by the adoption of a prepublication judicial review procedure patterned after the New York model. ${ }^{230}$ Although public officials assume the risk of increased scrutiny due to the nature of their office, they retain a substantial interest in protecting their reputation from a report's explicit or implicit finding that they have violated the public trust. The only opportunities to respond to a report after its release may be in the public forum or through a motion to expunge. These opportunities may be inadequate, however, as the former merely offers the official the possibility of partial exoneration and the latter may be granted too late to undo the harm caused by an unsubstantiated report. $^{231}$

Prepublication review provides a judicial forum in which the official can block the release of an unsubstantiated report. During the review, the grand jury should be required to establish that the official's

grand jury's investigation would be included within this category of reports.

In contrast, the Watergate report would not be included within this category since, even if the President was immune from prosecution while in office, his conduct was qualitatively sufficient to indict once he was no longer in office.

${ }^{228}$ Cf. N.Y. Crim. Proc. Law $\S 190.85(1)(\mathrm{b})$ (McKinney 1982) (authorizing the grand jury to issue reports "[s]tating that after investigation of a public servant it ifinds no misconduct, non-feasance or neglect in office by him provided that such public servant has requested the submission of such report").

${ }^{230}$ See supra text accompanying notes 95-110.

231 See United States v. Connelly, 129 F. Supp. 786, 787-88 (D. Minn. 1955) ("The mere expunging of the report at this date would not remove any adverse effect of . . . publicity. Rather, the result might be that further publicity would flow from such ruling."), aff'd on other grounds sub nom. Brennan v. United States, 240 F.2d 253 (8th Gir.), cert. denied, 353 U.S. 931 (1957); In re Report of Grand Jury, 39 Md. App. 472, 477, 386 A.2d 1246, 1249 (expungement is "a hollow victory" after a report is published in newspapers), cert. denied, $283 \mathrm{Md}$. 734 (1978). 
violation of the public trust is not regulated by the criminal law, and the court should delete any portions of the report that suggest criminal misconduct. ${ }^{232}$ Regardless of whether it is a requirement of procedural due process, ${ }^{233}$ prepublication review is necessary to protect an official from the possibility of grand jury abuse. By doing so, it promotes public confidence in the fairness of the reporting process.

\section{Quantitative Insufficiency}

Reports that reveal violations of the public trust where the evidence of misconduct is quantitatively insufficient to indict ${ }^{\mathbf{2 3 4}}$ are closely related to those that reveal violations that are qualitatively insufficient. In both instances, an official has violated the public trust and the grand jury is unable to reveal the violation by indictment. Moreover, when there exists a possibility of criminal misconduct, but the evidence is quantitatively insufficient to indict, the public interest in learning of violations of the public trust is at least as strong as when the misconduct is not regulated by the criminal law. Nevertheless, unlike a report that reveals evidence that is qualitatively insufficient to indict, one that reveals evidence that is quantitatively insufficient will be vulnerable to objections that it is indistinguishable from an indictment and was used by the grand jury as an alternative to a criminal prosecution.

One can respond to the objection that such a report resembles a criminal indictment in two ways. First, if the grand jury concludes that the official's misconduct is not indictable, the report should explicitly exonerate the official of criminal wrongdoing. Any possible interpretation that the report suggests criminality could be minimized if evidence susceptible to such an interpretation is deleted. However, this approach is unlikely to satisfy supporters of the reporting authority who will assert the public's right to know all the evidence relevant to the official's misconduct. An alternative approach would be to follow each portion of the report that could be interpreted to suggest criminality with a re-

${ }^{232}$ If the official's misconduct is regulated by the criminal law, or the report otherwise suggests criminality, the public might view the report as the equivalent of a criminal indictment, despite the grand jury's finding that exonerated the official of criminal misconduct.

${ }^{233}$ See supra note 73.

234 To illustrate, recall the hypothetical discussed supra note 4 and assume that reported campaign contributions are specifically included within coverage of the bribery statutes. Assume further that there is some evidence to suggest that the official was aware of the contribution before taking action but that the evidence on this point is conflicting and insufficient to establish probable cause that a crime occurred. Nevertheless, if the evidence establishes that the official took the action to benefit the contributor and disregarded the public interest, a report that revealed the official's conduct would be included within this category of report. 
statement of the grand jury's finding that exonerates the official of criminal wrongdoing. This approach furthers the public's right to know all the relevant evidence, while it protects the official's reputation from unjustified suggestions of criminal misconduct.

Second, the objection that a report was used as an alternative to criminal prosecution can be eliminated by requiring prepublication review of the grand jury's determination that there is insufficient evidence to indict. If that determination was not reviewable, a grand jury could issue a report that exonerates an official of criminal misconduct yet reveals overwhelming evidence of criminality. Such a report, despite its finding exonerating the official, is likely to be viewed publicly as the equivalent of a criminal accusation. ${ }^{236} \mathrm{~A}$ court, during prepublication review, can prevent both of these possibilities by ensuring that there is a reasonable basis for the grand jury's conclusion that there is insufficient evidence to indict. ${ }^{236}$

${ }^{235}$ Furthermore, without prepublication review of the indictability issue, a grand jury could avoid the prohibition suggested later in this Article against using a report as an alternative to a prosecution simply by exonerating the official of criminal misconduct even though it concludes that the misconduct is indictable. See infra text accompanying notes 250-60.

238 The reasonable basis standard for review proposed in the text is intended to allow the grand jury substantial discretion in determining whether or not evidence is quantitatively insufficient to indict. This discretion is consistent with the deference given by most courts to the grand jury's conclusion that there is sufficient evidence to initiate a prosecution.

Although federal grand juries are required to find probable cause that the defendant committed a crime in order to indict, the Supreme Court has precluded an attack on an indictment on the ground that there was insufficient evidence to indict. In Costello v. United States, 350 U.S. 359 (1956), the Court held that "[a]n indictment returned by a legally constituted and unbiased grand jury, like an information drawn by the prosecutor, if valid on its face, is enough to call for trial of the charge on the merits." Id. at 363 (footnote omitted); see also Lawn v. United States, 355 U.S. 339, 348-50 (1958) (stating that valid indictment is not open to challenge on the grounds that the evidence presented before the grand jury was inadequate or incompetent). Similarly, most state courts preclude an attack on an indictment based on the ground that there was insufficient evidence before the grand jury to establish probable cause. See generally 2 S. BEALE \& W. BRYSON, supra note 7, \& 10.20 (courts largely refuse to consider challenges to nature or sufficiency of evidence supporting indictment); $2 \mathrm{~W}$. LAFAVE \& J. IsRaEL, supra note $24, \S 15.4$ (c) (compiling state court decisions).

It can be argued that, in the case of the reporting function, the grand jury's determination that there is insufficient evidence to indict should not be reviewable, as is its determination that there is sufficient evidence to initiate a prosecution. Not having heard the testimony of grand jury witnesses, a court is unable to adequately assess questions of witness credibility that are central to the grand jury's decision whether or not to indict. The burden placed on a court to determine whether there is insufficient evidence to indict may not outweigh the possibility that a report that exonerates an official of criminality could nevertheless be publicly viewed as the equivalent of a criminal accusation.

The argument against judicial review is appealing, but it does not consider that one of the purposes of review is to determine whether the report has been used as an 


\section{B. Reports Revealing Violations of the Public Trust When the Grand Jury Is Uncertain Whether or Not the Misconduct Is Indictable}

In some investigations the grand jury and prosecutor may be uncertain as to whether or not an official's misconduct is indictable. Quantitative evidentiary problems, however, are unlikely to be the cause of such uncertainty. Grand juries routinely apply probable cause or prima facie evidence standards in initiating prosecutions, ${ }^{237}$ and if a grand jury concludes that there is insufficient evidence to indict, it can prepare a report. ${ }^{238} \mathrm{~A}$ more common cause of uncertainty as to the indictability of an official's misconduct will be qualitative evidentiary problems, since the criminality of the conduct often depends on unsettled questions of law.

When the qualitative sufficiency of the evidence is in doubt, the grand jury and prosecutor will be hesitant to indict but, at the same time, reluctant to issue a report that exonerates the official of criminal wrongdoing. The grand jury's hesitancy to indict will arise from its realization that the evidentiary issue may lead a judge either to dismiss an indictment for failure to allege an offense or to reverse a conviction. When the qualitative sufficiency of the evidence is in doubt, the grand jury and prosecutor may conclude that it is inappropriate to require the state to initiate a prosecution and unfair to require the official to defend herself against criminal charges. A finding that exonerates the official of criminal wrongdoing, however, may be premature, since the official's violation of the public trust, in the end, may be regulated by the criminal law.

There are two alternative ways for a grand jury to exercise its reporting authority when it is uncertain whether or not misconduct is

alternative to a prosecution. Later in this Article, it is argued that the public interest will not be served if the grand jury decides that a report is more effective than a prosecution to hold an official accountable for a criminal violation of the public trust. See infra text accompanying notes 245-62. Prepublication review of the quantitative sufficiency of the evidence helps ensure that a report has not been used as an alternative to a prosecution.

The standard of review proposed in the text requires judicial review but minimizes the burden imposed on the court. The review standard does not require the court to determine whether or not the official's misconduct is indictable, but only whether there is a reasonable basis for the grand jury's conclusion. This standard should be easy to apply and adequate to deter the grand jury from using this type of report as an alternative to a prosecution.

237 See supra note 114 and accompanying text.

${ }^{238}$ The report should still be subject to prepublication review where the court must determine whether there is a reasonable basis for the grand jury's conclusion. See supra note 236 and accompanying text. 
regulated by the criminal law. Under the first, the grand jury can prepare a report that reveals the official's misconduct and discusses why the criminality of that conduct is questionable under existing law. ${ }^{239}$ The report could also state the grand jury's conclusion that it would be inappropriate to initiate a prosecution because of the uncertain coverage of the substantive law. During prepublication review, the court should determine that the indictability of the official's misconduct is unsettled before it releases the report. ${ }^{240}$ Although this type of report does not specifically exonerate the official of criminal misconduct, the inference of criminality is significantly mitigated by the grand jury's acknowledgement that the misconduct might not be regulated by the criminal law.

The second alternative is to require the grand jury to prepare a report that exonerates the official of criminal misconduct. The qualitative evidentiary issue would then be determined during prepublication review. If the court concludes that the official's misconduct is not regulated by the criminal law, the report will be released. However, if the court concludes that the misconduct is indictable, it should bar publication of the report and give the grand jury the opportunity to indict the official.

This approach ostensibly accommodates the interests of both the public and the official. If the official's misconduct is held to be indictable during prepublication review, the grand jury's reluctance to indict will be alleviated, and a prosecution will be initiated. Alternatively, if the misconduct is found not to be regulated by the criminal law, the report will specifically exonerate the official of criminal misconduct and will not be challenged as being indistinguishable from a criminal accusation. There is, nevertheless, a significant problem with this approach. Requiring judicial determination of qualitative evidentiary issues during prepublication review allows an official to object to a report on the basis that misconduct is indictable and therefore actionable only through a prosecution. ${ }^{241}$ The official may take this position after cal-

238 The Alaska Impeachment Report, in discussing the applicability of the crime of official misconduct to the Governor's conduct, followed a similar approach. See supra note 206.

${ }^{240}$ If the official's misconduct is clearly regulated by the criminal law, the public is likely to view the report as the equivalent of a criminal accusation despite the grand jury's statement that the coverage of the law is uncertain. In such a situation, the report should not be published.

${ }^{241}$ See supra note 119 (comments of Rep. Eckhart). Theoretically, the official could also raise a similar objection when the grand jury prepares a report after concluding that the official's misconduct is qualitatively insufficient to indict. See supra text accompanying notes 228-34. However, for that category of report, the nonindictability of the official's misconduct will be readily apparent, see supra note 
culating that, even if the court agrees, the grand jury and prosecutor may still be unwilling to indict because of uncertainty as to whether the evidence is quantitatively sufficient to establish a crime at a trial. Moreover, the prosecutor might hesitate to recommend indictment out of fear that a conviction will be reversed on appeal because of a holding on the qualitative evidentiary issue contrary to the one rendered during prepublication review. Thus, it may be in the best interests of an official to argue that alleged misconduct is indictable if this strategy results in nonpublication of the report, followed by a grand jury decision not to indict. ${ }^{242}$ Should this occur, the official's misconduct will not be revealed, and the public interest in learning of the violation of the public trust will be frustrated. Alternatively, if the grand jury decides to indict, there remains the possibility that the official will be acquitted even though she violated the public trust. Because the second alternative forces the grand jury to initiate a prosecution to reveal an indictable violation of the public trust, it raises the issue of whether the grand jury should have the authority to use the reporting function as an alternative to a prosecution.

\section{The Use of a Report as an Alternative to a Prosecution}

As the Alaska Impeachment Report illustrates, a grand jury sometimes issues a report even though it has concluded that a public official has committed an indictable violation of the public trust. If the evidence uncovered by a grand jury is both quantitatively and qualitatively sufficient to indict, the publication of a report is not the sole means of disclosing the official's violation of the public trust. Indeed, the only public interests furthered by such a report concern the possible advantages of the report as an alternative to prosecution. Those perceived advantages were discussed by Special Counsel Frampton in his remarks to the Alaska grand jury.

Frampton argued that a report allows the grand jury to publicize official wrongdoing in a more comprehensive and timely manner than it could through a prosecution. ${ }^{243}$ Following release, an outraged public presumably would react quickly to the evidence of misconduct and de-

228 , and it is therefore extremely unlikely that the official will make or succeed in the argument discussed in the accompanying text.

${ }^{242}$ This strategy also carries high risks for the official. If the court agrees that the misconduct is indictable, and a prosecution is initiated, the official is exposed to the possibility of a criminal sanction. Additionally, by arguing during prepublication review that the misconduct is qualitatively sufficient to indict, the official has most likely precluded her ability to make a contrary argument in attempting to have a conviction reversed on appeal.

${ }^{243}$ See supra text accompanying notes 186-89. 
mand that the official be held accountable. If the official is subject to constitutionally or statutorily prescribed removal or disciplinary proceedings, the public may call for the initiation of those proceedings. If the official serves at the pleasure of an appointing authority, the public may pressure that authority to dismiss the official. Consequently, the report may be viewed as being preferable to a prosecution because it might bring about the official's removal or discipline with greater expediency. ${ }^{244}$ These goals may seem more important to the grand jury and prosecutor than the possibility of a criminal sanction. ${ }^{245}$

Since prepublication judicial review is essential to the reporting function when a grand jury reveals misconduct that is not indictable, ${ }^{248}$ the need for that review is even more critical when a report is used as an alternative to prosecution. Since the release of a report does not by itself provide an adversarial forum for an official to answer the grand jury's express or implied charges of criminal misconduct, the official should at least have the opportunity to test the accuracy of the report before publication. However, prepublication review eliminates the perceived advantage of a report as a device that comprehensively reveals the official's misconduct more quickly than an indictment. Assuming that the official objects to release, and recognizing that the report will remain sealed throughout the judicial review and appeal process, ${ }^{247}$

244 The Alaska Impeachment Report in fact publicized the Governor's alleged misconduct in a timely and detailed fashion. One day after the grand jury completed its comprehensive report, the report was released. The grand jury completed its report on July 1, 1985. See AlasKa IMPEACHMENT RePORT, supra note 16, at 69. The report was released on July 2, 1985. See Grand Jury Transcript, supra note 177, at 2724. The speed with which the report was released, however, was only possible because prepublication judicial review was virtually nonexistent, and the Governor did not have the opportunity to review and object to the report before release, and did not participate in the initial judicial release decision. See id. at 2722-24; see also Alaska Judicial CouncIL, supra note 16, at 8 (Prosecutors filed a brief in support of grand jury's request that report be made public; "no other parties participated in the hearings on this request.").

${ }^{248}$ Standards that regulate prosecutorial discretion recognize that a decision to decline prosecution may be based on a conclusion that the public interest can best be served by the noncriminal disposition of a case. See U.S. DEPARTMENT OF JusTICE, supra note 114, at B.1.(d) (1980) (prosecutor with probable cause to believe crime has been committed may decline prosecution and recommend a noncriminal disposition); $i d$. at B.2.(c) (prosecution may be declined if there exists an adequate noncriminal alternative to prosecution); id. at B.5.(a) (in deciding whether to decline prosecution in favor of noncriminal disposition, the prosecutor may consider all relevant factors including "the sanctions available under the alternative means of disposition"); see also STANDards Relating to the Prosecution Function § 3.9(b) (Approved Draft 1971) ("The prosecutor may in some circumstances and for good cause consistent with the public interest decline to prosecute, notwithstanding that evidence exists which would support a conviction.").

246 See supra notes 230-33 and accompanying text.

247 See supra text accompanying notes 98-101. 
there is likely to be a substantial delay between the report's preparation and its publication. ${ }^{248}$ The grand jury's goal of immediately publicizing the official's misconduct would be better served by an indictment since indictments are not subject to judicial review prior to release. ${ }^{249} \mathrm{Al}-$ though the indictment is unlikely to disclose as many of the relevant facts as a report, it will highlight the general "theory of the case," and additional information will be revealed during the pretrial proceedings.

Even with the delay inherent in prepublication review, the grand jury might still conclude that publication of a report is preferable to prosecution. There are at least two possible reasons for that conclusion: first, the grand jury may calculate that a report, even with its delayed publication, will still result in the official's removal or discipline more quickly than a prosecution; second, the grand jury may recognize that prosecution creates the possibility that the official may be acquitted and claim exoneration, even though the official's conduct violated the public trust. ${ }^{250}$ While these reasons suggest that a grand jury should not always be required to choose between an indictment and a no-true bill whenever it identifies an indictable violation of the public trust, they do not support the conclusion that the third alternative available to the grand jury should be a public report that reveals the official's misconduct.

When a report is used as an alternative to prosecution, the grand jury has in fact passed the buck to an authority with the ability to discipline or remove the official. Unless that authority acts in response to the report, however, the official will escape any direct and immediate sanction for the misconduct, and absent statutory or constitutional authorization, a grand jury is powerless to require that the removing or disciplinary authority proceed against the official. ${ }^{201}$ Thus, if the grand

${ }^{248}$ Cf. Costello v. United States, 350 U.S. 359, 363 (1955) (In a case that involved review of the sufficiency of evidence behind a grand jury indictment, Justice Black noted that "[i]f indictments were to be held open to challenge on the ground that there was inadequate or incompetent evidence before the grand jury, the resulting delay would be great indeed.").

${ }^{249}$ See id. ("An indictment returned by a legally constituted and unbiased grand jury ... if valid on its face, is enough to call for a trial of the charge on the merits. The Fifth Amendment requires nothing more.").

250 Both reasons were considered by the Alaska grand jury in deciding to forego prosecution of the Governor. See supra text accompanying notes 186-94.

${ }^{281}$ Under the Judicial Councils Reform and Judicial Conduct and Disability Act of 1980, Pub. L. No. 96-458, 94 Stat. 2035, the judicial council may certify to the Judicial Conference that grounds for impeachment of a federal judge exist, and if the Conference agrees, it "shall so certify and transmit the determination and the record of proceedings to the House of Representatives for whatever action the House of Representatives considers to be necessary." 28 U.S.C. $\$ \S 372(c)(7)(B),(c)(8)(1982)$; In interpreting this statute, the Eleventh Circuit held that although the judicial council can make an impeachment recommendation, the House has the sole power to impeach and 
jury does not indict, and if no action is taken by the authority in response to the report, the public interest in holding the official accountable for violating the public trust will be frustrated. ${ }^{262}$

Frustration of the public interest may also occur if the removing or disciplinary authority acts on the grand jury's recommendation. ${ }^{253}$ Once a removal or disciplinary proceeding is initiated, the official will almost certainly use that forum to attack the legality of the report. ${ }^{254}$ Doubts about the legality of a report will in turn call into question the overall fairness of the grand jury's investigation, and give the official's political supporters a reason not to act on the grand jury's findings. ${ }^{255}$ Consequently, even if the report survives prepublication review and triggers the initiation of a removal or disciplinary action, the focus of that inquiry may shift from the alleged misconduct of the official to the legality of the grand jury report.

If the removing or disciplinary authority does act in response to the report, the official's responsibility for violating the public trust could be judged by a standard of conduct that is more demanding of the official, ${ }^{256}$ and by a standard of proof that is less demanding of society, than would be applicable in a criminal prosecution. ${ }^{257}$ A stricter standard of conduct and a reduced burden of proof are two significant advantages of foregoing prosecution to determine, outside of a criminal trial, the official's accountability for violating the public trust. In combination, these advantages remove the possibility that the official can claim exoneration because misconduct, although a violation of the public trust, is insufficient to establish the elements of a crime beyond a

"is free to act upon [the council's] information or ignore it, as it chooses." In re Certain Complaints Under Investigation, 783 F.2d 1488, 1511 (11th Cir.), cert. denied sub nom. Hastings v. Gobold, 106 S. Ct. 3273 (1986).

${ }^{262}$ In the case of reports that concern elected public officials, one could argue that publication of the report by itself holds the official accountable since the evidence revealed can be considered by the public in the next election.

${ }^{205}$ A report such as the Alaska Impeachment Report may effectively leave the disciplinary or removing authority little choice but to quickly proceed against the criticized official. Politically, at least, it may be impossible to ignore a report that calls for an official's removal and explicitly or implicitly accuses the official of a criminal violation of the public trust.

${ }^{254}$ Cf. supra note 19 (citing public criticisms of the Alaska Impeachment Report).

${ }^{255}$ See Fairbanks Daily News-Miner, Aug. 29, 1985, at 1, col. 1 (quoting conclusions of Governor's counsel and the counsel to the State Senate that impeachment proceedings were conducted on a partisan basis).

${ }^{268}$ By not indicting, the grand jury seeks to have a violation of the public trust judged under the demanding fiduciary duties standards imposed on public officials rather than within the narrower definition of criminal conduct.

${ }^{257}$ For example, during the Alaska impeachment hearings the burden of proof for establishing an impeachable offense was set at a "clear and convincing" evidence standard. See supra note 16. 
reasonable doubt. ${ }^{258}$

As the above discussion indicates, however, it is questionable whether a public report can accomplish the grand jury's goals of foregoing prosecution. The perceived advantage of a report-comprehensively and quickly revealing the official's misconduct-may be eliminated by prepublication judicial review. Even if the report is released, there is no assurance that the removing or disciplinary authority will proceed against the official. Even if it does, questions as to the report's legality may detract from the weight given to the grand jury's findings. ${ }^{289}$ The use of a report as an alternative to the prosecution of an indictable offense, therefore, is not guaranteed to accomplish any significant benefit for the public.

Statutory authorization to use a public report as an alternative to prosecution would only slightly improve the likelihood that the report will accomplish the grand jury's goals. That authorization only removes the "shadow of illegality" 280 surrounding the report; it does not allow the report to be released as quickly as an indictment, nor does it require the removing or disciplinary authority to act in response to the report. Unless the grand jury's decision to forego prosecution promptly requires consideration of its evidence in a removal or disciplinary action against a public official, the use of a report as an alternative to a prosecution should be beyond the scope of the reporting authority.

\section{Adapting the Reporting Function to Provide a Viable Alternative to Prosecution When a Violation of the Public Trust Is Indictable}

Although the release of a public report is ill-suited to further the grand jury's goals in foregoing prosecution, the reporting function can

${ }^{288}$ Of course, there is nothing to prevent a removal or disciplinary action against the official after an indictment or at the conclusion of a criminal trial. But if the primary concern of the grand jury is the prompt disciplining or removal of the official, the question of whether or not the violation of the public trust is quantitatively and qualitatively sufficient to support a conviction is largely irrelevant. Although the gravity of the misconduct will in part be measured by whether it violates the criminal law, the criminality of the misconduct is not dispositive as to whether the public trust has been violated. The initiation of a prosecution, however, may effectively merge the two issues in the minds of the public and the removing or disciplinary authority. The question of whether criminal liability can be established may become synonymous with the issue of whether the public trust has been violated. Once the official is indicted, there may be a reluctance to begin removal or disciplinary proceedings until the criminal case is resolved, and if the official is acquitted, there may be a corresponding reluctance to initiate a noncriminal inquiry.

${ }^{259} C f$. supra note 16 (quoting remarks of Sen. Ferguson).

260 Kuh, supra note 6, at 1103; see also supra note 7. 
be adapted to provide a viable alternative to prosecution. One such alternative exists in several states, where the grand jury may conclude an investigation of official misconduct by recommending the removal of public officials holding specified offices. ${ }^{261}$ The recommendation may be based on an accusation that the official committed a noncriminal or a criminal violation of the public trust. ${ }^{262}$ A removal proceeding is automatically initiated in response to the grand jury's recommendation ${ }^{263}$ and, in that proceeding, the state's attorney or a local district or county attorney must establish the official's misconduct. ${ }^{264}$ The proceeding is heard by a jury, ${ }^{285}$ and the official is entitled to cross-examine witnesses and to present a defense. ${ }^{268}$ Removal is automatic if the grand jury's accusation of misconduct is established. ${ }^{207}$ Several states require

${ }^{261}$ See, e.g., N.M. STAT. ANN. $\S \S 10-4-1,-4-3$ (1978) (any elected county, precinct, district, city, town or village officer elected by the people); N.D. CENT. CoDE § 44-10-02 (1978 \& Supp. 1987) ("district, county, township, city, or municipal officer, school board member, or any state officer not liable to impeachment"); OKLA. STAT. ANN. tit. 22, $\S \S 1181,1182$ (West 1986) ("[a]ny officer not subject to impeachment elected or appointed to any state, county, township, city, town, or other office"); UTAH CODE ANN. §§ 77-6-1 to -6-2 (1982) ("justices of the peace and all officers of any city, county or other political subdivision ... not liable to impeachment").

${ }^{262}$ See, e.g., N.M. STAT ANN. § 10-4-2 (1978) (several grounds including conviction of a crime, "failure, neglect or refusal to discharge any duty devolving upon the officer by virtue of his office" and "gross incompetency or gross negligence in discharging the duties of the office"); N.D. CENT. CoDE $\S 44-10-02$ (1978 \& Supp. 1987) (several grounds including "misconduct, malfeasance, crime, or misdemeanor in office . . . or gross incompetency"); OKLA. STAT. ANN. tit. 22, § 1181 (West 1986) (several grounds including "habitual or willful neglect of duty" and "corruption in office"); UTAH CODE ANN. § 77-6-1 (1982) ("high crimes and misdemeanors or malfeasance in office").

${ }^{263}$ See, e.g., N.M. STAT. ANN. § 10-4-5 (1978) (district attorney shall serve a copy of the accusation on the accused and require that she appear before the district court and answer); N.D. Gent. Code $\S$ 44-10-04, -05 (1978) (same); OKLA. STAT. ANN. tit. 22, § 1184 (West 1986) (same); UTAH Code ANN. § 77-6-4 (1982) (same). 204 See, e.g., N.M. STAT. ANN. $\S 10-4-5$ (1978) (district attorney); N.D. CENT. CODE $\S$ 44-10-04 (1978) (state's attorney); OKLA. STAT. ANN. tit. 22, § 1184 (West 1986) (district attorney); UTAH CODE ANN. $\$ 77-6-4$ (1982) (county attorney).

${ }^{28 s}$ See, e.g., N.M. STAT. ANN. $\S 10-4-12$ (1978) (trial must be by jury); N.D. Cent. Code § 44-10-11 (1978) (same); OkLa. Stat. ANN. tit. 22, § 1191 (West 1986) (same); UTAH CoDE ANN. § 77-6-77 (1982) (statute refers to court trial, but official is allowed a jury trial, see Madsen v. Brown, 701 P.2d 1086, 1089 (Utah 1985)).

${ }^{268}$ See, e.g., N.M. STAT. ANN. $§ 10-4-12$ (1978) (trial to be conducted in the same manner as a trial on an information or indictment for a misdemeanor); N.D. Cent. Code § 44-10-11 (1978) (same); Okla. Stat. AnN. tit. 22, § 1191 (West 1986) (same); UTAH CODE ANN. § 77-6-7 (1982) (procedures for civil trial apply).

${ }_{267}$ See, e.g., N.M. STAT. ANN. $\S 10-4-14$ (1978) (The court must pronounce judgment that the defendant be removed from office upon conviction.); N.D. CENT. CoDE \& 44-10-12 (1978) (same); OKLa. STAT. ANN. tit. 22, § 1192 (West 1986) (same); UTAH CODE ANN. § 77-6-8 (1982) ("The court shall enter judgment against him directing the defendant be removed from office."). 
that the accusation be established beyond a reasonable doubt, ${ }^{268}$ while others require the accusation to be proved by a preponderance of the evidence. ${ }^{269}$

This procedure incorporates many of the advantages that the grand jury seeks, but does not necessarily realize, when it uses a public report as an alternative to a prosecution. Since the grand jury's removal recommendation automatically triggers an adversarial proceeding, the basis for that recommendation is not subject to judicial review before release. ${ }^{270}$ The grand jury can therefore quickly publicize an official's misconduct even though the official has not been indicted. The grand jury is also assured that the official's responsibility for violating the public trust will be determined in a proceeding in which the legality of the decision to forego prosecution is not in dispute. Finally, the official can be removed for violating the public trust regardless of whether that violation constitutes a crime. The official can therefore be held accountable under a stricter standard of conduct than that required by the criminal law, and it is impossible for the official to claim exoneration because the breach of fiduciary duty may have been insufficient to establish criminal liability.

This removal procedure does not, however, address all of the situations in which a grand jury may wish to forego prosecution in order to take some other action to hold an official accountable for violating the public trust. Since the grand jury's accusation must trigger a removal proceeding, the grand jury is unable to initiate any action short of removal, such as censure or discipline. The removal procedure could be expanded, however, to permit the grand jury to initiate a disciplinary proceeding against the official or to trigger a proceeding before an ethics commision or comparable agency.

In cases where a public official is subject to constitutionally-prescribed removal or impeachment proceedings, the grand jury is precluded from automatically initiating that procedure through its accusa-

288 See, e.g., Mitchell v. Medler, 17 N.M. 644, 651, 131 P. 976, 979 (1913) ("[A] person who has been elected to an office . . . is not to be summarily removed . . . until his dereliction is made to appear beyond all reasonable doubt."); State v. Raedeker, 158 Okla. 248, 251, 13 P.2d 148, 150 (1932) ("beyond a reasonable doubt").

${ }^{289}$ See, e.g., State v. Borstad, 27 N.D. 533, 540, 147 N.W. 380, 382-83 (1914) (statute provides for civil rules on trial; jury instruction requiring "fair preponderance of the evidence" proper); Madsen v. Brown, 701 P.2d 1186, 1091 (Utah 1985) (unanimous verdict not required); see also UTAH CODE ANN. § 77-6-7 (1982) ("The rights of the parties and the procedures used shall be the same as in any civil proceeding.").

${ }^{270}$ Since the grand jury's removal recommendation can be based on a finding of criminal or noncriminal misconduct, prepublication review is not required to determine whether the report has been used as an alternative to prosecution. See supra notes 23435 and accompanying text. 
tion. ${ }^{271}$ Similarly, officials who are constitutionally subject to removal or discipline at the discretion of their appointing authority may not be covered by a removal procedure automatically initiated by a grand jury. ${ }^{272}$ For the former category of official, the circumstances illustrated by the Watergate grand jury investigation and report provide another example of how the reporting function can be adapted to provide a viable alternative to prosecution.

In instances where a constitutionally prescribed removal proceeding has already been initiated, the grand jury should have the authority to conclude its investigation by transmitting evidence to the removing authority even though that evidence may support a criminal indictment. Under these circumstances the grand jury is assured that its evidence will be considered in determining the official's accountability for violating the public trust, and the official is assured of an adversarial forum in which to challenge the grand jury's findings.

\section{CONCLUSION}

In most criminal investigations, the grand jury performs two roles: it shields the accused from unjustified prosecution and it acts as a sword with which the state can bring the guilty to justice. In cases that involve misconduct by public officials, however, the grand jury historically has performed a third role by publicizing violations of the public trust, even though the misconduct may have been insufficient to establish a violation of the criminal law. The common law grand jury, by assuming this watchdog role over government and public officials, furthered a worthwhile objective. At the same time, however, the reporting function planted the seeds of conflict between the grand jury's two primary roles.

The reporting function combines aspects of the grand jury's sword and shield roles. The grand jury's ability to investigate and report on official misconduct serves as a sword that holds public officials account-

${ }^{271}$ See, e.g., N.D. CENT. CoDE $§ 44-10-02$ (1978 \& Supp. 1987) (Written accusation of public officer by grand jury may be presented to district court except against "a representative in Congress [or] a member of the legislative assembly . . . ."); OKLA. STAT. ANN. tit. 22, § 1181 (West 1986) ("Any officer not subject to impeachment . . . may be removed from office" based on written accusation of grand jury.); UTAH CODE ANN. § 77-6-1 ("All . . officers . . . not liable to impeachment shall be subject to removal" based on written accusation of grand jury.); cf. I $\dot{n}$ re Certain Complaints Under Investigation, 783 F.2d 1488, 1511 (11th Cir.), cert. denied sub nom. Hastings v. Gobold, 106 S. Cit. 3273 (1986) (While judicial council can recommend impeachment, House of Representatives is free to ignore that recommendation.).

${ }_{272}$ Cf. Myers v. United States, 272 U.S. 52 (1926) (statute requiring congressional consent for removal of officer of the United States held unconsitutional as restricting president's power to remove appointed officer). 
able under a stricter standard of conduct than that required by the criminal law. At the same time, the report must shield the official from accusations of misconduct that are not supported by the evidence. The report accuses, but not in the same way as an indictment; it shields, but not in the same way as a no-true bill.

The authority to reveal violations of the public trust without initiating a prosecution remains one of the most controversial functions of the modern grand jury. Despite that controversy, grand juries continue to exercise a watchdog role over government by revealing official misconduct without returning an indictment. As the Alaska Impeachment Report illustrates, the reporting function is sometimes exercised even though a public official could have been indicted.

The appropriate scope of the reporting function can be defined by focusing on the issues of why the grand jury prepares its report and whether or not the violation of the public trust uncovered during its investigation is indictable. If the violation is not regulated by the criminal law or if there is insufficient evidence to indict, the reporting function furthers the compelling interest of protecting the public's right to know about the conduct of government officials. In doing so, the report helps to hold officials accountable under a stricter standard of conduct than that required by the criminal law. By taking office, a public official voluntarily assumes an increased risk of scrutiny that should include the possibility that violations of the public trust will be revealed through a judicially regulated reporting function designed to minimize abuse and to maximize accuracy.

If the grand jury is uncertain as to whether or not misconduct is regulated by the criminal law, a report that reveals the misconduct and explicitly acknowledges the uncertain criminal nature of the conduct furthers the public interest by publicizing a violation of the public trust. The reporting function, under these circumstances, minimizes the possibility that the state will devote scarce resources to pursuing a prosecution of questionable merit simply to reveal noncriminal misconduct. Although the report is susceptible to an interpretation suggesting criminal wrongdoing, the official's interest in requiring a grand jury criminal accusation to be established at trial beyond a reasonable doubt is substantially reduced. The report does not accuse the official of criminal misconduct but instead concedes that the criminality of the violation of the public trust is uncertain.

A different balance between the public and private interests implicated by the reporting function is required when the grand jury concludes that misconduct is indictable but nevertheless prepares a report as a preferred alternative to prosecution. The goals that a grand jury 
seeks to achieve by foregoing prosecution may be in the best interests of society, but a public report is unlikely to accomplish those objectives. The public interest in holding an official accountable for violating the public trust is more likely to be hindered than furthered when the grand jury foregoes prosecution in favor of issuing a report.

When a report is used as an alternative to prosecution, the interests of the public official are entitled to substantial weight. Because the report reveals indictable misconduct it is likely to be viewed publicly as the equivalent of a criminal accusation. Since the grand jury concluded that the misconduct was indictable, its report cannot exonerate the official of criminal wrongdoing or acknowledge that indictability is uncertain. Even if the report concedes that it may be diffficult to establish guilt beyond a reasonable doubt, it will still convey the grand jury's belief that the misconduct is indictable. Since publication of the report does not ensure the creation of an adversarial forum for response, the official's interest in requiring an explicit or implicit grand jury accusation of criminal misconduct to be established at trial beyond a reasonable doubt outweighs the public interest that is arguably furthered by the report. Unless the reporting function is adapted to provide that the grand jury's decision to forego prosecution requires prompt consideration of its evidence in a disciplinary or removal proceeding, the use of a report as an alternative to a prosecution should be beyond the scope of the grand jury's authority. 